\title{
Strengthening of the Efferent Olivocochlear System Leads to Synaptic Dysfunction and Tonotopy Disruption of a Central Auditory Nucleus
}

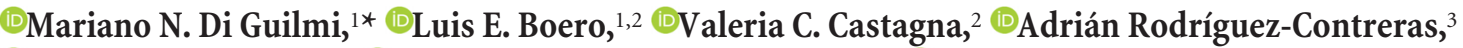 \\ ๑Carolina Wedemeyer, ${ }^{1}{ }^{\circledR}$ María Eugenia Gómez-Casati, ${ }^{2}$ and ${ }^{\circledR}$ Ana Belén Elgoyhen ${ }^{1,2 *}$ \\ ${ }^{1}$ Instituto de Investigaciones en Ingeniería Genética y Biología Molecular, Dr. Héctor N. Torres, INGEBI-CONICET, Buenos Aires, Argentina C1428ADN, \\ ${ }^{2}$ Instituto de Farmacología, Facultad de Medicina, UBA, Buenos Aires, Argentina C1121ABG, and ${ }^{3}$ Department of Biology, City College of New York, \\ New York, NY 10031
}

The auditory system in many mammals is immature at birth but precisely organized in adults. Spontaneous activity in the inner ear plays a critical role in guiding this maturation process. This is shaped by an efferent pathway that descends from the brainstem and makes transient direct synaptic contacts with inner hair cells. In this work, we used an $\alpha 9$ cholinergic nicotinic receptor knock-in mouse model (of either sex) with enhanced medial efferent activity (Chrna9L9' $T, L 9^{\prime} T$ ) to further understand the role of the olivocochlear system in the correct establishment of auditory circuits. Wave III of auditory brainstem responses (which represents synchronized activity of synapses within the superior olivary complex) was smaller in $L 9^{\prime} T$ mice, suggesting a central dysfunction. The mechanism underlying this functional alteration was analyzed in brain slices containing the medial nucleus of the trapezoid body (MNTB), where neurons are topographically organized along a mediolateral (ML) axis. The topographic organization of MNTB physiological properties observed in wildtype (WT) was abolished in $L 9^{\prime} T$ mice. Additionally, electrophysiological recordings in slices indicated MNTB synaptic alterations. In vivo multielectrode recordings showed that the overall level of MNTB activity was reduced in the $L 9^{\prime} T$. The present results indicate that the transient cochlear efferent innervation to inner hair cells during the critical period before the onset of hearing is involved in the refinement of topographic maps as well as in setting the properties of synaptic transmission at a central auditory nucleus.

Key words: $\alpha 9 \alpha 10$ nAChR; Chrna9L9' T; efferent MOC inhibition; MNTB; tonotopy

Significance Statement

Cochlear inner hair cells of altricial mammals display spontaneous electrical activity before hearing onset. The pattern and firing rate of these cells are crucial for the correct maturation of the central auditory pathway. A descending efferent innervation from the CNS contacts the hair cells during this developmental window. The present work shows that genetic enhancement of efferent function disrupts the orderly topographic distribution of biophysical and synaptic properties in the auditory brainstem and causes severe synaptic dysfunction. This work adds to the notion that the transient efferent innervation to the cochlea is necessary for the correct establishment of the central auditory circuitry.

\section{Introduction}

The strength and physiological properties of synaptic inputs, the accurate organization of neuronal circuits, and the formation of topographic maps in the mature brain are established during development through activity-dependent processes that involve reorganization and fine-tuning of immature synaptic and cellular networks (Goodman and Shatz, 1993; Hanson and Landmesser,
Received Oct. 2, 2018; revised June 10, 2019; accepted June 14, 2019.

Author contributions: M.N.D.G., M.E.G.-C., and A.B.E. designed research; M.N.D.G., L.E.B., V.C.C., A.R.-C., C.W., and M.E.G.-C. performed research; M.N.D.G., L.E.B., V.C.C., C.W., and M.E.G.-C. analyzed data; M.N.D.G. wrote the first draft of the paper; M.N.D.G., L.E.B., A.R.-C., C.W., M.E.G.-C., and A.B.E. edited the paper; A.R.-C., M.E.G.-C., and A.B.E. contributed unpublished reagents/analytic tools.

This work was supported by Agencia Nacional de Promoción Científica y Tecnológica to A.B.E. and M.N.D.G., Fondation Pour I'Audition Scientific Grand Prize to A.B.E., and National Institutes of Health Grant R01 DC001508 to Paul A. Fuchs and A.B.E. and SC1DC015907 to A.R.-C. M.N.D.G. received the Company of Biologist travelling fellowship DEVTF-160703 and a "Bec.Ar" fellowship for a short stay supported by the Argentinian government. We thank
Eleonora Katz, Lucas G. Vattino, and Marcelo J. Moglie for critical reading of the manuscript; Juan D. Goutman for fruitful discussion and assistance with data analysis through routines implemented in Igor Pro; and Claudia Gatto for excellent technical assistance.

The authors declare no competing financial interests.

Correspondence should be addressed to Ana Belén Elgoyhen at elgoyhen@dna.uba.ar or abelgoyhen@gmail.com or Mariano N. Di Guilmi at mndiguilmi@dna.uba.ar.

https://doi.org/10.1523/JNEUROSCI.2536-18.2019

Copyright $\odot 2019$ the authors 
2004; Kirkby et al., 2013). The auditory system in many mammals is very immature at birth but precisely organized in adults. Spontaneous activity in the inner ear during an early developmental critical period comes into play to guide this process (Lippe, 1994; Kotak and Sanes, 1995; Jones et al., 2007; Tritsch et al., 2007; Sonntag et al., 2009). Spontaneous activity, driven by calcium action potentials (APs) in the inner hair cells (IHCs) (Kros et al., 1998; Glowatzki and Fuchs, 2000; Marcotti et al., 2003; Tritsch et al., 2007; Johnson et al., 2011), is essential for several processes related to the survival of target neurons in the cochlear nucleus (Leake et al., 2006), the accurate wiring of auditory pathways (Friauf and Lohmann, 1999), and the refinement of tonotopic maps in the lateral superior olive (Kandler, 2004; Clause et al., 2014).

A distinctive feature of IHCs during the prehearing critical period is the presence of direct axo-somatic efferent medial olivocochlear (MOC) synaptic contacts, which disappear at hearing onset (Warr and Guinan, 1979; Simmons et al., 1996). This synapse is cholinergic (Glowatzki and Fuchs, 2000; Katz et al., 2004; Gómez-Casati et al., 2005) and is mediated by a highly calcium-permeable $\alpha 9 \alpha 10 \mathrm{nAChR}$ present in the IHCs (Elgoyhen et al., 1994, 2001; Weisstaub et al., 2002; Lipovsek et al., 2012) coupled to the activation of small-conductance calciumactivated SK2 potassium channels (Glowatzki and Fuchs, 2000). Exogenously applied acetylcholine (Glowatzki and Fuchs, 2000) or electrical stimulation of the efferent terminals (Goutman et al., 2005; Wedemeyer et al., 2018) inhibits IHC APs. Therefore, it has been proposed that cholinergic efferent inhibition of IHCs might impose rhythmicity to the generation of IHC APs and the spontaneous activity of the auditory pathway during the critical period preceding hearing onset (Glowatzki and Fuchs, 2000; Johnson et al., 2011; Sendin et al., 2014; Moglie et al., 2018). However, this notion has been challenged (Tritsch et al., 2010); therefore, the function of the developmental efferent innervation is still a matter of debate.

Clause et al. (2014) showed that, in $\alpha 9 \mathrm{KO}$ mice, which lack efferent activity (Vetter et al., 1999, 2007), the spike patterning of spontaneous activity at the medial nucleus of the trapezoid body (MNTB) level is altered. This leads to a reduced permanent sharpening of functional topography (Clause et al., 2014) and to the impairment of sound localization and frequency processing (Clause et al., 2017), indicating a role of the efferent system in the development of central auditory nuclei. The present work shows an alternative approach in which we used an $\alpha 9$ knock-in mouse model $\left(L 9^{\prime} T\right)$ with enhanced efferent activity (Taranda et al., 2009), leading to sustained inhibition of IHC AP generation (Wedemeyer et al., 2018). Since a decrease of efferent modulation leads to an alteration in the functional topography (Clause et al., 2014), one could a priori hypothesize that the enhancement of efferent strength might lead to hyper-refinement of topographic properties. To this end, we analyzed the calyx of Held-MNTB synapse, making focus on MNTB innervation, its synaptic features, and topography. Synaptic transmission was greatly impaired in $\alpha 9 L 9^{\prime} T$ mice. Moreover, the proportion of immature "small"-evoked postsynaptic currents (EPSCs) was significantly enhanced in $L 9^{\prime} T$ mice. Contrary to our hypothesis, a complete lack of topographic organization of the MNTB was observed. These results, together with those of Clause et al. (2014), provide clear evidence that a tight regulation of prehearing spontaneous activity, brought about by the transient MOC innervation to the IHCs, is crucial for the development of the central auditory pathway.

\section{Materials and Methods}

Animals and experiments. Generation of the knock-in mouse $\left(L 9^{\prime} T\right)$ has been described previously (Taranda et al., 2009). WT or homozygous $L 9^{\prime} T$ mice of either sex were used. All experimental protocols were performed in accordance with the American Veterinary Medical Associations' AVMA guidelines on euthanasia (2013) and approved by the Institutional Animal Care and Use Committee at Instituto de Investigaciones en Ingeniería Genética y Biología Molecular and City College of New York.

Auditory brainstem responses (ABRs). Animals of postnatal days 14 (P14), P16, and P21 were anesthetized with a mix of xylazine $(10 \mathrm{mg} / \mathrm{kg}$ i.p.)/ketamine (100 mg/kg i.p.), and needle electrodes were inserted at vertex and pinna, with a ground near the tail. ABRs were evoked with 5 $\mathrm{ms}$ tone pips $(0.5 \mathrm{~ms}$ rise-fall, $\cos 2$ onset, at $35 / \mathrm{s})$. The response was amplified $(10,000 \times)$ filtered $(0.1-3 \mathrm{kHz})$, and averaged with an A-D board in a LabVIEW-driven data-acquisition system (National Instruments; RRID:SCR_014325). Sound level was raised in $5 \mathrm{~dB}$ steps from 20 to $80 \mathrm{~dB}$ SPL. At each level, 1024 responses were averaged (with stimulus polarity alternated), using an "artifact reject" whereby response waveforms were discarded when peak-to-peak amplitude exceeded $15 \mu \mathrm{V}$. Upon visual inspection of stacked waveforms, "threshold" was defined as the lowest SPL level at which a wave could be detected. ABR wave I amplitude was measured baseline to positive first peak, and waves II-V were measured peak to peak, computed by offline analysis of stored waveforms using Clampfit 10.3 (Molecular Devices).

Electrophysiology on MNTB slices. For slice recordings, 50 mice of either sex between 12 and 14 postnatal days old were used. Their brains were removed rapidly after decapitation and placed into an ice-cold low$\mathrm{Ca}^{2+}$ aCSF solution. This solution contained the following (in mM): 125 $\mathrm{NaCl}, 2.5 \mathrm{KCl}, 3 \mathrm{MgCl}_{2}, 0.1 \mathrm{CaCl}_{2}, 1.25 \mathrm{NaH}_{2} \mathrm{PO}_{4}, 0.4$ ascorbic acid, 3 myoinositol, 2 pyruvic acid, $25 \mathrm{D}$-glucose, and $25 \mathrm{NaHCO}_{3}$. The brainstem was glued on a cooled chamber of a vibrating microslicer (Vibratome, 1000 Plus, Ted Pella). Transverse slices (300 $\mu \mathrm{m}$ thickness) containing the MNTB were sequentially cut and transferred into an incubation chamber containing normal aCSF at $37^{\circ} \mathrm{C}$ for $30 \mathrm{~min}$. After incubation, slices were allowed to return to room temperature. Normal aCSF had the same composition as the slicing solution, except that the $\mathrm{MgCl}_{2}$ and $\mathrm{CaCl}_{2}$ concentrations were 1 and $2 \mathrm{~mm}$, respectively. The $\mathrm{pH}$ was 7.4 when gassed with $95 \% \mathrm{O}_{2}$ and $5 \% \mathrm{CO}_{2}$.

Whole-cell patch-clamp recordings. Slices were transferred to an experimental chamber. During recording, slices were continuously perfused with carbogenated $\left(95 \% \mathrm{O}_{2} / 5 \% \mathrm{CO}_{2}\right)$ aCSF maintained at room temperature $\left(22^{\circ} \mathrm{C}-25^{\circ} \mathrm{C}\right)$. Medial $(\mathrm{M})$ and lateral (L) MNTB principal cells were compared to evaluate topographic differences. The position of these two opposite groups of cells was determined during the experiment according to the morphological landmark delimited by the middle line (M) and the VII cranial nerve (L). Lucifer yellow $(0.3 \mathrm{mg} / \mathrm{ml}$; Sigma-Aldrich) was added to the internal solution to certify the position at the end of the experiment. MNTB neurons were visualized using a Carl Zeiss Axioskop microscope and viewed with differential interference contrast by a $40 \times$ water-immersion objective ( 0.8 numerical aperture water-immersion objective) and a camera with contrast enhancement (DMK 23UP1300, Imaging Source). Whole-cell recordings were made with patch pipettes pulled from thin-walled borosilicate glass (World Precision Instruments; RRID:SCR_008593). Electrodes had resistances of 3.8-4.5 $\mathrm{M} \Omega$. Potassium currents were isolated by an internal solution containing the following (in $\mathrm{mM}$ ): $121.3 \mathrm{~K}$-gluconate, $20 \mathrm{KCl}, 10 \mathrm{HEPES}, 10$ phosphocreatine, 0.5 EGTA, $4 \mathrm{Mg}$-ATP, and 0.3 Li-GTP. Additionally, the external solution was supplemented with $1 \mu \mathrm{M}$ TTX, $50 \mu \mathrm{M} \mathrm{CdCl} 2$, and $10 \mu \mathrm{M}$ ZD7288. Hyperpolarization-activated currents $\left(\mathrm{I}_{\mathrm{h}}\right.$-type) were analyzed from recordings in the presence of TTX $(1 \mu \mathrm{M})$ and TEA $(20 \mathrm{mM})$. The $\mathrm{pH}$ was adjusted to 7.3 with $\mathrm{KOH}$. The pipette solution used for isolating synaptic currents was (in mM) as follows: $135 \mathrm{Cs}-\mathrm{MeSO}_{3}, 13$ TEA-Cl, 5 HEPES, $3.5 \mathrm{MgCl}_{2}, 0.1 \mathrm{CaCl}_{2}, 2.5 \mathrm{Na}_{2}$-ATP, and 1 EGTA, $\mathrm{pH} 7.2(\mathrm{CsOH})$. Liquid junction potential was uncompensated in both solutions.

Patch-clamp recordings were made using an Axopatch 200A amplifier (Molecular Devices), a Digidata 1320 (Molecular Devices), and pClamp 
9.0 software (Molecular Devices; RRID:SCR_011323). Data were sampled at $50 \mathrm{kHz}$ and filtered at $4-6 \mathrm{kHz}$ (low-pass Bessel). Series resistances ranged from 6 to $15 \mathrm{M} \Omega$. Whole-cell membrane capacitance $(15-25 \mathrm{pF})$ was registered from the amplifier after compensation of the transient generated by a $10 \mathrm{~ms}$ voltage step. To elicit APs, positive current steps (250 pA) during $500 \mathrm{~ms}$ were applied. Thus, the delay in AP generation for the same current step was compared in medial and lateral cells. Voltage-clamp protocols were as follows: the cell was held at a resting potential of $-50 \mathrm{mV}(1 \mathrm{~s})$ and stepped to a range of $-130 \mathrm{mV}$ to $-40 \mathrm{mV}$ for $500 \mathrm{~ms}$ (in increments of $5 \mathrm{mV}$ ). $\mathrm{I}_{\mathrm{h}}$ amplitude was measured as instantaneous $\left(\mathrm{I}_{\mathrm{I}}\right)$ minus slowly inward $\left(\mathrm{I}_{\mathrm{s}}\right)$ current $\left(\mathrm{I}_{\mathrm{s}}-\mathrm{I}_{\mathrm{I}}\right)$ (Yi et al., 2010). Statistical comparisons were evaluated at its maximal current amplitude $(-140 \mathrm{mV})$. ZD7288 $(50 \mu \mathrm{M})$ or $\mathrm{CsCl}(1 \mathrm{mM})$ was used to confirm the presence of an $I_{h}$ current. No leak current was subtracted from any of the raw current traces for the $I_{h}$ current. Potassium currents were elicited by square depolarizing pulses of $1 \mathrm{~s}$ from -90 to $40 \mathrm{mV}$. Offline leak subtraction was performed for $\mathrm{K}^{+}$currents, and the average current at the steady-state (within the last $50 \mathrm{~ms}$ ) is reported.

Miniature EPSCs (mEPSCs) were recorded continuously for at least three separate periods of $1 \mathrm{~min}$. Amplitude and frequency were analyzed using Clampfit 10.3 (Molecular Devices) and Mini Analysis Program (Synaptosoft; RRID:SCR_002184). Events with a maximal duration of 5 $\mathrm{ms}$ and decay time $<1.5 \mathrm{~ms}$ were considered (Taschenberger et al., 2005; Rusu and Borst, 2011). EPSCs were evoked by stimulating the globular bushy cell axons in the trapezoid body at the midline using a hand-made bipolar platinum electrode and an isolated stimulator (Digitimer DS3; $0.1 \mathrm{~ms}$ duration and 2-20 mA amplitude). Strychnine ( $1 \mu \mathrm{M})$ was added to the aCSF to block inhibitory glycinergic synaptic responses. Classification of "small" and "large" EPSC was made according to the literature. Typically, a canonical mature MNTB EPSC amplitude ("large") is in the 5-15 nA range (Barnes-Davies and Forsythe, 1995; Borst et al., 1995; Erazo Fischer et al., 2007; Xiao et al., 2013). In the present work, it was > $4 \mathrm{nA}$ in WT animals. On the contrary, poly-innervated MNTB cells display "small" EPSC amplitudes in the pico-amperes range (RodríguezContreras et al., 2008), and they were $<1 \mathrm{nA}$ in the present work. Additionally, both types of current amplitudes display different stimulus-intensity behavior. "Large" (mono-innervated) EPSCs are independent from stimulus intensity, whereas "small" (multi-innervated) EPSCs are dependent on stimulus intensity (see Fig. 5) due to the increased number of fibers which are recruited as the stimulus is raised. Data distribution was evaluated by fitting with a Gaussian function (extreme value distribution) with the Statistica Software (Stat Soft; RRID: SCR_014213). This distribution allows to evidence the largest extreme.

Analysis of electrophysiological data. Electrophysiological recordings were analyzed using Clampfit 10.3 (Molecular Devices) and custom routines in Igor 6.2 (Wavemetrics; RRID:SCR_000325). Igor routines were used to perform offline leak subtraction (for potassium currents). Series resistances of EPSC recordings were $\sim 50 \%-70 \%$ compensated. The remaining Rs error of postsynaptic currents was corrected by an offline Igor routine.

In vivo electrophysiological recordings. The surgical procedures used are those described by Rodríguez-Contreras et al. (2008), with some minor modifications. Neonate (P7-P8) mice pups were initially anesthetized with isoflurane (3\%, carried by oxygen). Animals were tracheotomized, intubated, and mechanically ventilated using a MiniVent type 845 mouse ventilator (Harvard Apparatus; 190 breaths per minute, 30-40 $\mu$ l stroke volume). During surgery, anesthesia was reduced to $1.5 \%$ and carefully monitored on the basis of pedal reflexes. A small craniotomy $(1.5 \times 1.5$ $\mathrm{mm}$ ) was performed, and the vascular landscape constituted by the basilar artery and the anterior inferior cerebellar artery was exposed. The dura was carefully removed. A silicon probe (polytrode $4 \times 4$ 16-channel arrays, NeuroNexus, A4x4-3 mm-50-125-177-A16; 1 M $\Omega$ ) was coated with the lipophilic dye DiI (Invitrogen) for histological analysis after recording to confirm proper targeting to the MNTB. Recordings were acquired for $10 \mathrm{~min}$, and isoflurane was kept at $0.5 \%$. All data from the silicon probe were sampled $(20 \mathrm{kHz})$, amplified, and digitized in a singlehead stage (Intan RHD200-RHD2216, Intan Technologies). The signal obtained from the electrode was low-pass filtered (Butterworth, 4 poles, cutoff frequency $300 \mathrm{~Hz}$ ) and processed by Offline Sorter 4.4 (Plexon).
Spikes with amplitudes $>0.5 \%$ of the threshold noise were considered. Multiunit activity collected in different active channels in every polytrode was averaged.

Experimental design and statistical analysis. Experiments were designed to reduce the number of animals but taking into account a balance between the number of samples to accurately perform statistical tests and the ethics guidelines for animal research as described above. Data analyses were done blind to genotype. All statistical tests were performed with Statistica 7.0 software (Stat Soft; RRID:SCR_014213) with the exception of ABRs performed with Prism 6 software (GraphPad; RRID:SCR_002798). Before performing any analysis, datasets were tested for normal distribution and homoscedasticity. If these assumptions were satisfactorily passed, a parametric test was applied. In these cases, comparisons were made by one-way ANOVA, and the statistic $F$ value with the associated $p$ value significance was reported in every case. Otherwise, nonparametric Mann-Whitney test was used. Values of $p<$ 0.05 were considered significant. Average data were expressed and plotted as mean \pm SEM. In all cases, $n$ indicates the number of cells tested, with the exception of ABRs and in vivo recordings where $n$ indicates the number of animals.

Drugs and reagents. All drugs and reagents were purchased from Sigma-Aldrich (RRID:SCR_008988), with the exception of ZD7288 and tetrodotoxin (TTX), which were purchased from Tocris Bioscience (RRID:SCR_003689).

\section{Results}

\section{The overall MNTB activity is reduced in $L 9^{\prime} T$ mice}

The MOC-IHC synapse of $L 9^{\prime} T$ mice displays both presynaptic and postsynaptic alterations leading to an enhancement and prolongation of inhibitory synaptic responses (Wedemeyer et al., 2018). Furthermore, low-frequency stimulation of MOC fibers allows a complete suppression of IHC APs in mutant mice (Wedemeyer et al., 2018). Developmental spontaneous activity generated in the cochlea is transmitted along the entire auditory pathway (Tritsch et al., 2010). To analyze whether MNTB spontaneous activity is altered in $L 9^{\prime} T$ mice, we recorded in vivo the multiunit activity at P7-P8 in an ensemble of MNTB cells using polytrodes (silicon multielectrode probes) in both genotypes (Fig. 1A). In WT mice, the mean MNTB firing rate (11.49 \pm 3.58 $\mathrm{Hz}, n=6$ animals) was larger than in $L 9^{\prime} T(2.53 \pm 0.43, n=8$ animals; Mann-Whitney $U$ Test, $Z=2.19, p=0.028)$. This indicates that the overall level of MNTB spiking activity is reduced in the $L 9^{\prime} T$ efferent gain-of-function mouse model compared with WT mice (Fig. 1B).

\section{Reduction of ABR wave III amplitude in $L 9^{\prime} T$ mice}

To examine whether this enhanced MOC efferent cholinergic strength and reduced overall MNTB spontaneous activity has an impact on the functionality of the auditory pathway, ABRs were measured at P16 (temporally close to the onset of hearing) and at P21 (considered as an auditory mature stage: Fig. 2; Tables 1, 2). ABR individual waves reflect the activation of subsequent auditory processing stations and were used as a functional hearing test that detects retro-cochlear abnormalities underlying hearing impairment (Karplus et al., 1988; Shapiro, 1988; Shaw, 1988). Pipevoked ABR waveform amplitudes were analyzed at $80 \mathrm{~dB}$ SPL for peaks corresponding to the auditory nerve (wave I), cochlear nucleus (wave II), and superior olivary complex (SOC) (wave III) at different frequencies $(8,16$, and $32 \mathrm{kHz})$ (Melcher et al., 1996; Kim et al., 2013) (Fig. 2A). Interestingly, peak III amplitude at $\mathrm{P} 16$ was reduced in $L 9^{\prime} T$ mice compared with WT at $8 \mathrm{kHz}$ and at all frequencies tested at P21 (Table 1; Fig. 2D). Given the wide variation between the amplitudes of wave I among animals, we normalized wave III amplitudes to those of wave I. Significant differences in amplitude ratios between WT and $L 9^{\prime} T$ mice were 
still observed at 16 and $32 \mathrm{kHz}$ at P21 (Table 1 ), indicating a central functional abnormality at the level of the SOC. Latencies were similar for both genotypes (Table 2), suggesting no alterations in the speed of transmission. These results show that cochlear enhancement of $\alpha 9 \alpha 10$ nAChR activity results in a central dysfunction at the brainstem level. Moreover, wave II amplitudes were also reduced in $L 9^{\prime} T$ mice at P16, but similar at P21 compared with WT (Table 1; Fig. 2C). These might indicate differential effects in the maturation of different nuclei of the auditory pathway in mutant mice. As recently shown (Boero et al., 2018), no abnormalities in peak I amplitude were observed in $L 9^{\prime} T$ compared with WT mice at 8, 16, and $32 \mathrm{kHz}$, either at P16 or P21 (Fig. 2B; Table 1). This suggests no gross alterations in the first synapse of the auditory pathway between IHCs and auditory nerve fibers in $L 9^{\prime} T$ mice. It should be noted that, although no overall wave I changes were observed in mutant mice, cochlear alterations have been reported in $L 9^{\prime} T$ since they have fewer ribbon synapses at the medial region and elevated auditory thresholds (Taranda et al., 2009; Boero et al., 2018).

\section{Impairment of synaptic transmission at the calyx of Held in $L 9^{\prime} T$ mice}

The reduction of ABR peak III amplitude in $L 9^{\prime} T$ mice temporally close to the onset of hearing raises the question of whether synaptic transmission at the MNTB level is altered in mice with enhanced MOC activity. To address this point, we performed synaptic studies on slices containing the glutamatergic MNTBcalyx of Held synapse. The rate and amplitude of mEPSCs (Fig. $3 A$ ) were recorded in the presence of TTX $(1 \mu \mathrm{M})$. No differences were observed in mEPSCs amplitude distributions in $L 9^{\prime} T$ compared with WT (Fig. 3Bi), even when comparing the mean amplitudes along the ML axis (WT M: $32.81 \pm 2.61 \mathrm{pA}, n=8,7$ animals; WT L: $28.37 \pm 2.79 \mathrm{pA}, n=12,8$ animals; ANOVA, $F=$ $1.21, p=0.285 ; L 9^{\prime} T$ M: $32.82 \pm 2.77$ pA, $n=18,14$ animals; $L 9^{\prime} T$ L: $34.28 \pm 1.55$ pA, $n=16,13$ animals; Mann-Whitney test, $Z=-0.66, p=0.512$; Fig. 3 Bii). However, mEPSC frequency displayed a larger dispersion in $L 9^{\prime} T$ mice (Fig. $3 C i$ ), due to an increased mean mEPSC frequency in the lateral region $(M$ : $2.52 \pm 0.56 \mathrm{~Hz}$; L: $7.17 \pm 1.94 \mathrm{~Hz}$; Mann-Whitney test, $Z=$ $-2.11, p=0.035)$, that was not observed in WT mice (M: $2.07 \pm$ $0.51 \mathrm{~Hz}$; L: $2.34 \pm 0.42 \mathrm{~Hz}$, ANOVA, $F=1.16, p=0.689$; Fig. $3 \mathrm{Cii})$. This result suggests that spontaneous transmitter release at the calyx of Held-MNTB synapse is altered in $L 9^{\prime} T$ mice.

Principal neurons of the MNTB receive synaptic input from a single giant calyx terminal that generates the stereotyped calyceal EPSC response, which is independent of stimulus intensity above threshold (Fig. 4A,E). A broader EPSC amplitude distribution in $L 9^{\prime} T$ compared with WT mice was observed at P12-P14 (Fig. 4B). Thus, while no significant differences in the unitary medial and lateral EPSC amplitudes were recorded in WT mice (M: $7.59 \pm$ $1.12 \mathrm{nA}, n=9,7$ animals; L: $7.35 \pm 0.95 \mathrm{nA}, n=10,8$ animals, ANOVA, $F=0.027, p=0.87)$, the evoked synaptic currents in the lateral side ( $5.07 \pm 0.87 \mathrm{nA}, n=12,11$ animals) of $L 9^{\prime} T$ mice were smaller compared with those of the medial side (8.05 \pm 1.37 $\mathrm{nA}, n=11,11$ animals, ANOVA, $F=5.07, p=0.0357$; Fig. $4 D$ ).
Interestingly, a broader dispersion of EPSC amplitudes in $L 9^{\prime} T$ (Cv: 0.681) compared with WT (Cv: 0.241) mice was still observed in P20-P24 mice (Fig. 4F). However, no significant differences in EPSC mean amplitudes in $L 9^{\prime} T$ compared with WT were evidenced at P20-P24. Together, these results suggest that both spontaneous and evoked synaptic transmission was impaired in $L 9^{\prime} T$ mice, with the lateral low-frequency region being the most affected.

\section{Immature synaptic responses in $L 9^{\prime} T$ principal cells}

During early development, presynaptic calyx of Held terminals make multiple small contacts on MNTB neurons. This is followed by an early stage of functional and structural transformation (Kandler and Friauf, 1993; Taschenberger et al., 2002; Wimmer et al., 2006; Rodríguez-Contreras et al., 2008) in which multiple inputs strengthen and compete until a final single innervation is established (Holcomb et al., 2013). These multiple early contacts elicit "small"-amplitude glutamatergic currents from each axon (Rodríguez-Contreras et al., 2008) (Fig. 5A, left) until a mature calyceal response is established displaying a large, stimulus-independent response (Fig. $5 A$, right). Thus, the proportion of "small" versus "large" responses is reduced with maturation (Rodríguez-Contreras et al., 2008). Given that both "large" and "small" excitatory inputs to MNTB can be distinguished by their electrophysiological profile, the prevalence of small currents in both genotypes was analyzed (Fig. 5B). The probability of finding "small" inputs in WT mice was 10\% (4 of 35 cells, 11 animals) at P12-P14, whereas this proportion was threefold larger in $L 9^{\prime} T$ mice reaching $31 \%$ (12 of 38 cells, 12 animals; $\chi^{2}=4.32$, df $=1, p=0.019$ ).

\section{Altered topographic organization of MNTB AP waveforms in $L 9^{\prime} T$ mice}

Figures 1-5 present evidence for both synaptic and connectivity impairments between calyx of Held terminals and MNTB principal cells in $L 9^{\prime} T$ mice. To analyze whether these alterations were also accompanied by the disruption of the MNTB topographic arrangement, the ML gradient of different biophysical neuronal properties was analyzed (Fig. $6 A$ ).

In the first place, we analyzed the neuronal resting properties. In WT mice, the resting membrane potential (RMP) was more depolarized for medial $(-54.27 \pm 0.47 \mathrm{mV}, n=7 ; 5$ animals $)$ 
A

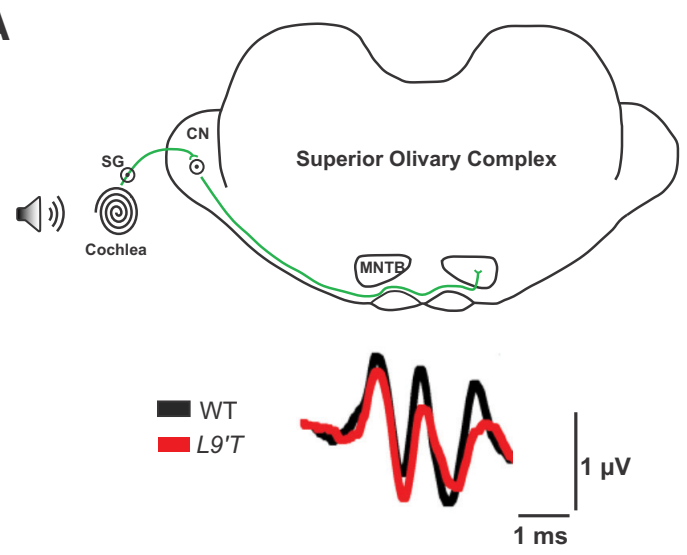

B
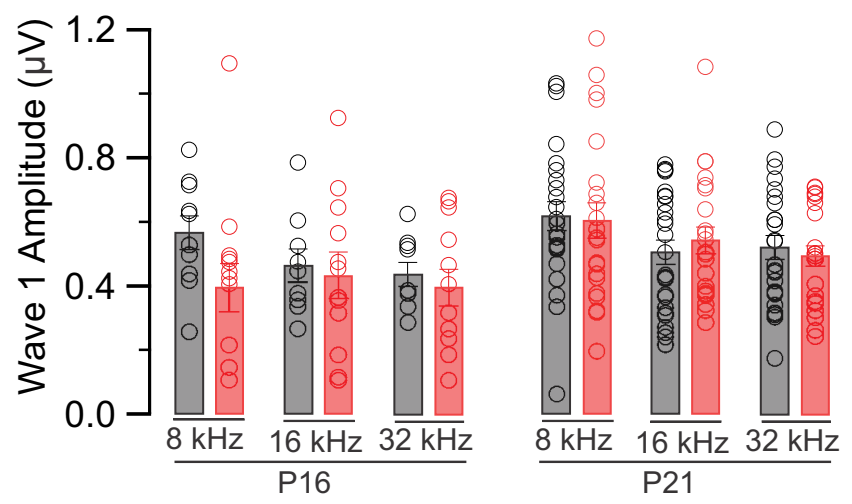

C

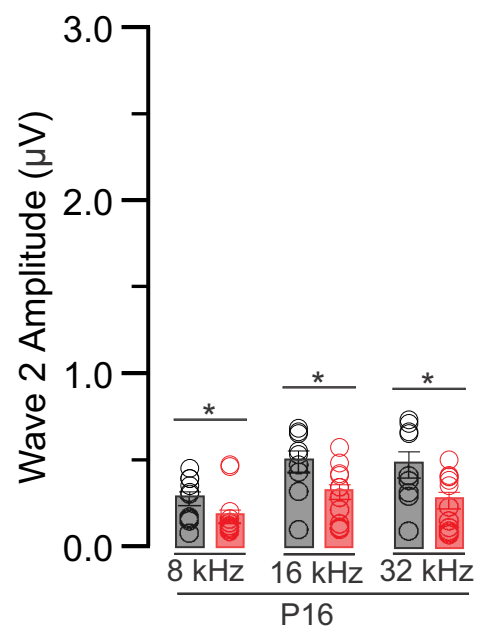

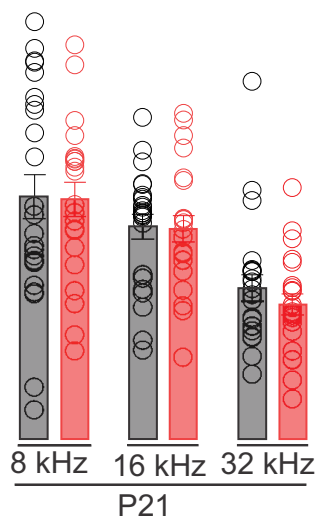

D
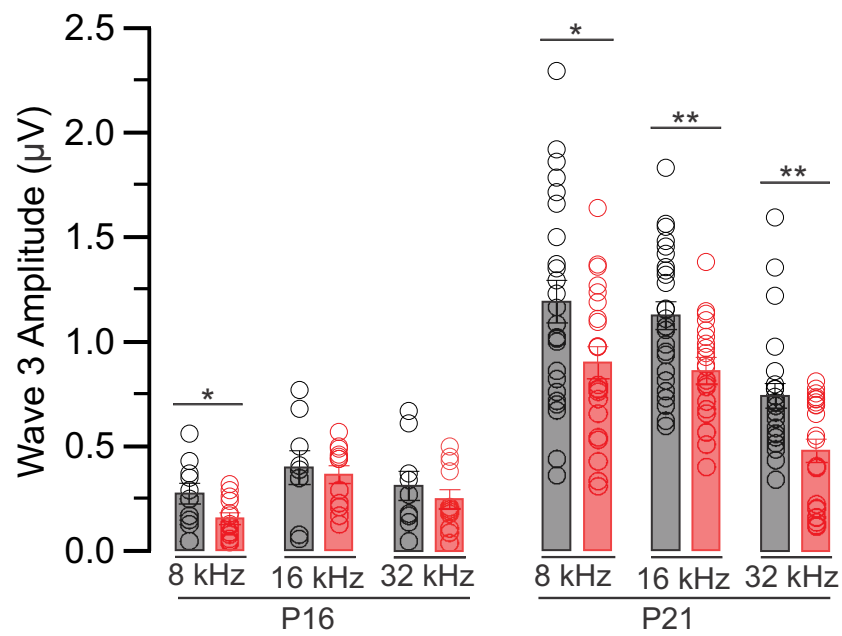

Figure 2. ABR wave III was smaller in $\angle 9^{\prime} T$ mice at P21. $A$, Schematic diagram of the brainstem at the level of the $S O C$ showing the cochlear stimulation with a speaker. Representative traces of ABRs of WT (black) and L9'T (red) mice at $80 \mathrm{~dB} \mathrm{SPL} / 32 \mathrm{kHz}$ showing waves I-III (bottom) at P21. ABR wave I (B), wave II (C), and wave III (D) amplitudes at $80 \mathrm{~dB}$ SPL for 8, 16, and $32 \mathrm{kHz}$, respectively, at P16 and P21. At P21, no significant differences were found for waves I and II at any of the frequencies tested. At this developmental age, however, $L 9^{\prime} T$ mice had lower wave III amplitudes at all the frequencies tested (ANOVA, $p<0.05$ ). Error bars indicate mean \pm SEM. See also Table $1 .{ }^{*} p<0.05,{ }^{* *} p<0.005$

Table 1. ABR peak amplitude quantification at $\mathrm{P} 16$ and $\mathrm{P} 21$

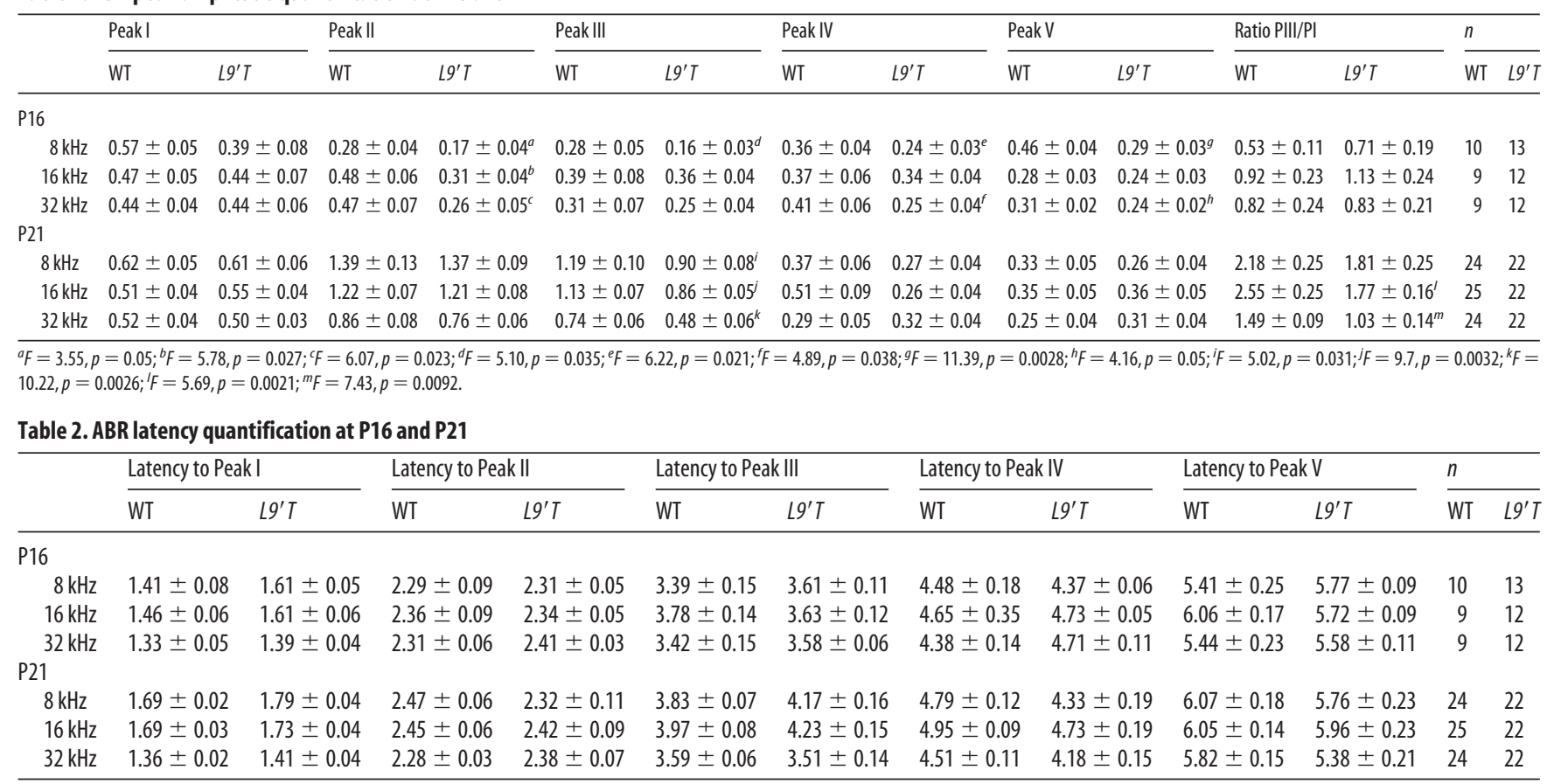


than lateral cells $(-59.49 \pm 0.36 \mathrm{mV}, n=$ 6, 5 animals; ANOVA, $F=9.33, p=$ 0.0013) (Fig. 6B). However, this difference was absent in the $L 9^{\prime} T$ mouse model (M: $-59.57 \pm 0.53 \mathrm{mV}, n=8,7$ animals; $\mathrm{L}:-58.57 \pm 0.79 \mathrm{mV}, n=7,7$ animals; ANOVA, $F=0.136, p=0.72$ ).

Like other neurons, MNTB principal cells can elicit an AP after a positive current injection (Fig. 6A) displaying waveform changes along the tonotopic map (Leao et al., 2006). MNTB cells in WT presented a topographic distribution in AP amplitudes ( $\mathrm{L}>\mathrm{M}, 8.6 \%$; Fig. $6 \mathrm{C}$ ), afterhyperpolarization $(\mathrm{M}>\mathrm{L}, 27.9 \%$; Fig. $6 D)$, area (L $>M, 42.9 \%$; Fig. $6 E)$, and delay ( $\mathrm{L}>\mathrm{M}$, 47.67\%; Fig. $6 F$ ). However, none of these parameters showed ML differences in $L 9^{\prime} T$ mice (Fig. 6C-F; Table 3). These results demonstrate that, contrary to WT mice, at the MNTB level, neither the RMP nor the AP waveform of MNTB principal cells shows an ML differential distribution in mice with enhanced MOC activity.

\section{Lack of ML gradient of potassium current amplitudes in $L 9^{\prime} T$ mice}

Hyperpolarization-activated cyclic nucleotide-gated (HCN) channels, permeable to both $\mathrm{Na}^{+}$and $\mathrm{K}^{+}$, are responsible for the inward $\mathrm{I}_{\mathrm{h}}$ rectifying current, which is present in many auditory neurons and can influence neuronal excitability (Bal and Oertel, 2000). The combination of $\mathrm{I}_{\mathrm{h}}$ and potassium currents allows the accurate relay of high-frequency auditory information across MNTB neurons and thus the fidelity by which timing information is computed (Hooper et al., 2002; Barnes-Davies et al., 2004; Hassfurth et al., 2009; Mathews et al., 2010; Karcz et al., 2011; Khurana et al., 2012; Baumann et al., 2013). The lateromedial gradient of these currents was analyzed in WT and $L 9^{\prime} T$ mice.

Repeated application of negative voltage steps from -50 to $-140 \mathrm{mV}$ displayed an instantaneous $\left(\mathrm{I}_{\mathrm{I}}\right)$ followed by a slowly inward $\left(\mathrm{I}_{\mathrm{s}}\right)$ current (Fig. $7 A$, inset), leading to an $\mathrm{I}_{\mathrm{h}}\left(\mathrm{I}_{\mathrm{s}}-\mathrm{I}_{\mathrm{I}}\right)$ current. The specificity of this inward current (mediated by HCN channels) was confirmed in all cases by its sensitivity to the selective blocker ZD7288 (Fig. 7A, inset). In agreement with previous observations (Leao et al., 2006), $\mathrm{I}_{\mathrm{h}}$ currents in WT mice exhibited a ML gradient (Fig. $7 B ;-140 \mathrm{mV}, \mathrm{M}:-372.74 \pm 35.48 \mathrm{pA}, n=$ 11, 8 animals; L: $-227.21 \pm 32.84 \mathrm{pA}, n=7,6$ animals, ANOVA, $F=7.89, p=0.013)$. However, in $L 9^{\prime} T$ mice, this difference was absent $(\mathrm{M}:-381.79 \pm 23.95 \mathrm{pA}, n=10 ; 7$ animals; $\mathrm{L}:-332.81 \pm$ 22.27, $n=9 ; 7$ animals, ANOVA, $F=2.22 ; p=0.156)$. The results obtained under voltage-clamp mode were further supported by current-clamp experiments. HCN channels can be activated by a hyperpolarizing current pulse injection, which generates a slow "sag" in the membrane potential (Banks et al., 1993; Koch et al., 2004). The sag amplitude in WT medial cells $(-51.84 \pm 4.13 \mathrm{mV}, n=9,8$ animals) was larger compared with that of the lateral region $(-39.54 \pm 4.78 \mathrm{mV}, n=10,8$ animals, ANOVA, $F=5.03, p=0.038)$. This difference was absent in $L 9^{\prime} T$ mice (M: $-56.86 \pm 6.74 \mathrm{mV}, n=7,6$ animals; $\mathrm{L}:-45 \pm 43 \mathrm{mV}$, $n=8,6$ animals; ANOVA, $F=2.05, p=0.17)$.

Potassium conductance was elicited in response to $1 \mathrm{~s}$ steps from $-90 \mathrm{mV}$ to $40 \mathrm{mV}$ in the presence of $\mathrm{CdCl}_{2}(50 \mu \mathrm{M})$, TTX
$\mathrm{B}_{i}$

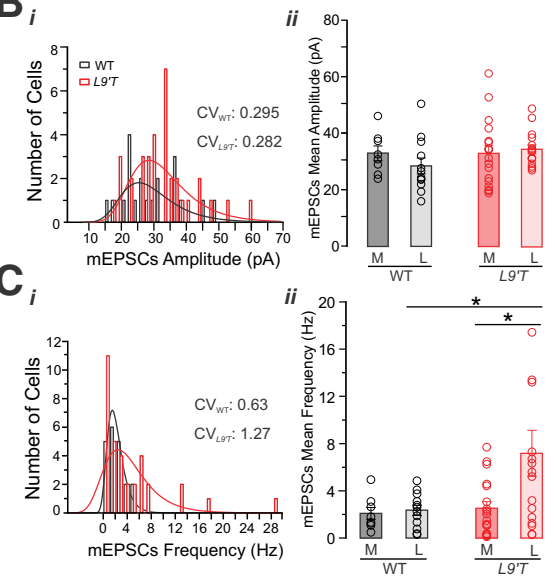

Figure 3. Altered spontaneous synaptic transmission in $L g^{\prime} T$ mice. $A$, Representative traces of mEPSCs for WT M (black), WT L (

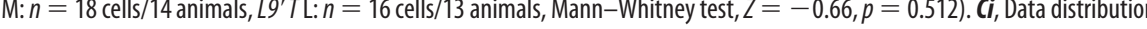
However, it was increased in the $L$ region of $L g^{\prime} T$ mice (Mann-Whitney test, $Z=-2.11 ; p=0.035$ ). ${ }^{*} p<0.05$.

(3 $\mu \mathrm{M})$, and ZD7288 $(50 \mu \mathrm{M})$ to block voltage-dependent calcium, sodium, and $\mathrm{I}_{\mathrm{h}}$ currents, respectively. Outward currents displayed a fast-small inactivating component and a large delayed noninactivating component (Fig. $7 C$, inset). Current-voltage relationships displayed topographic differences in WT mice. Thus, at $40 \mathrm{mV}$, the medial MNTB cells exhibited potassium currents of larger amplitude $(4.15 \pm 0.65 \mathrm{nA}, n=6,5$ animals $)$ than those of the lateral cells ( $2.07 \pm 0.11 \mathrm{nA}, n=6 ; 6$ animals; Mann-Whitney test, $Z=2.72, p=0.0065$ ) (Fig. $7 D$, inset). In contrast, $\mathrm{ML}$ differences were not observed in $L 9^{\prime} T$ mice (M: $4.83 \pm 0.99 \mathrm{nA}$, $n=6,6$ animals; L: $3.63 \pm 0.37 \mathrm{nA}, n=7,6$ animals; MannWhitney test, $Z=1.01, p=0.32$ ). In summary, potassium currents were not topographically distributed in the MNTB of $L 9^{\prime} T$ mice.

\section{Discussion}

By using mice with a mutation in the $\alpha 9 \mathrm{nAChR}$ rendering increased suppression of IHC activity (Taranda et al., 2009; Wedemeyer et al., 2018), we show electrophysiological alterations at the glutamatergic MNTB-calyx of Held synapse during the developmental critical period. An overall reduction of MNTB spontaneous spiking activity and synaptic dysfunction together with a lack of lateromedial gradients in several functional properties of the MNTB were observed. These alterations remaining after hearing onset were reflected in the overall ABR wave III amplitude reduction.

It has been suggested that the origin of IHC spontaneous spiking activity is located in the Kölliker's organ that triggers waves of ATP (Tritsch et al., 2007), leading to firing of developing IHCs (Tritsch and Bergles, 2010; Wang et al., 2015). Alternatively, it has been postulated that spontaneous activity is intrinsically generated by the hair cells (Johnson et al., 2011, 2012). A tight regulation of the pattern of IHC APs is a key feature for auditory development (Johnson et al., 2011, 2013; Sendin et al., 2014). Patterned spiking activity is propagated to spiral ganglion cells (Jones et al., 2007; Tritsch and Bergles, 2010; Tritsch et al., 2010), brainstem auditory nuclei (Lippe, 1994; Sonntag et al., 2009; Tritsch et al., 2010; Clause et al., 2014), and auditory cortex 
A
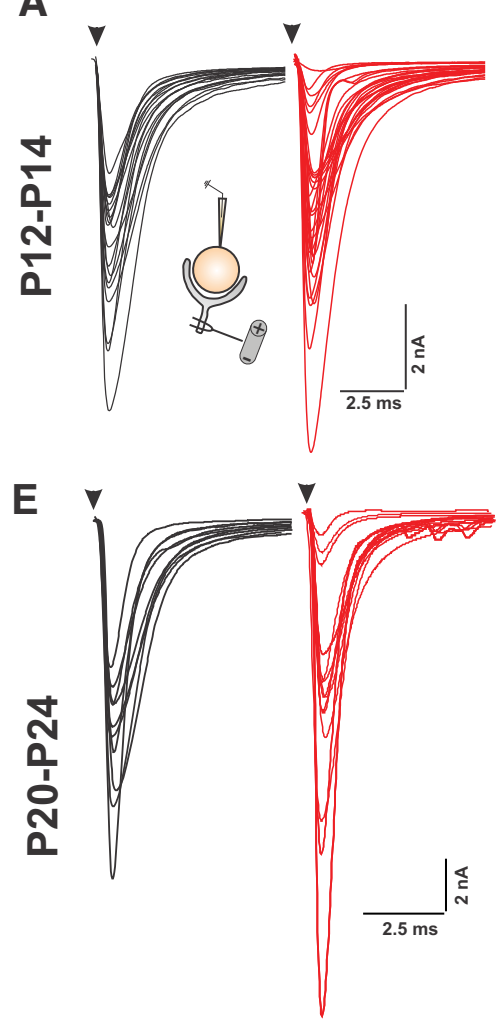

B

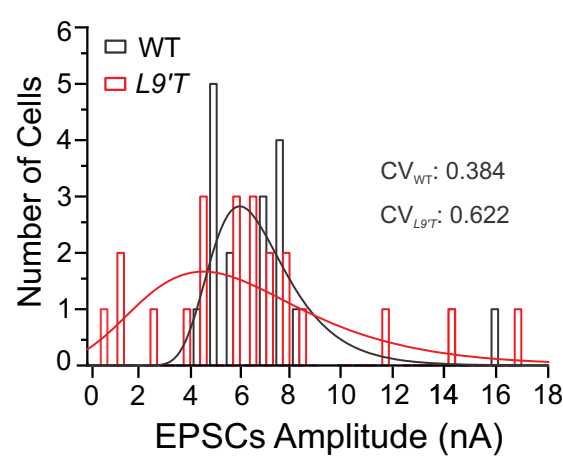

$F$

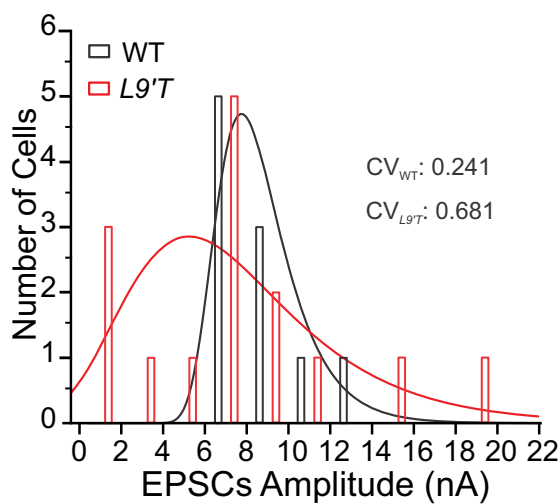

C

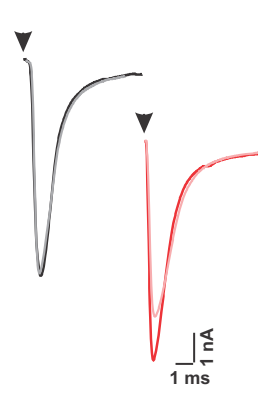

G

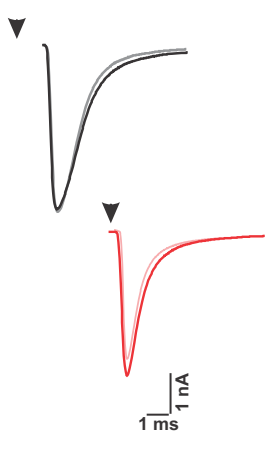

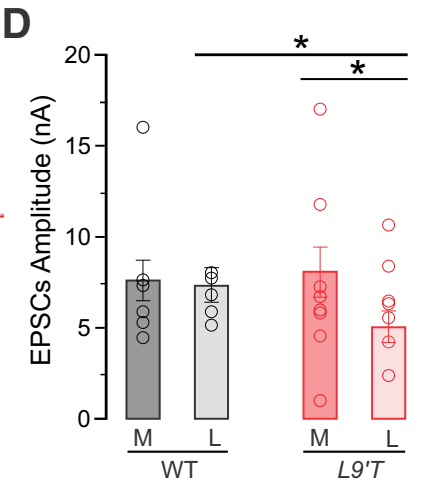

H

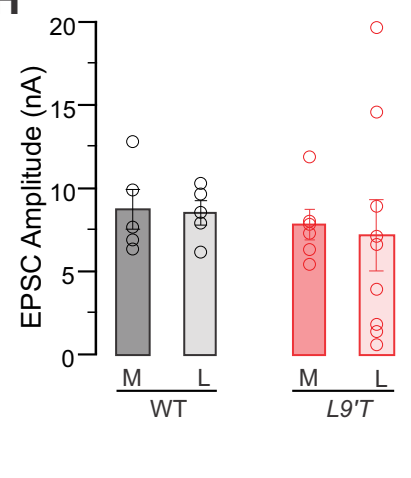

Figure 4. Altered evoked synaptic transmission in $L 9^{\prime} T$ mice. Representative traces of evoked EPSCs of MNTB principal cells for WT (black) and $L 9^{\prime} T($ red) at P12-P14 (A) and P20-P24 (E). Histogram distribution of EPSC amplitudes for both genotypes at different developmental stages $(\boldsymbol{B}, \boldsymbol{F})$. Histogram fitting with a Gaussian curve evidenced larger tails at lower amplitudes in $\angle 9^{\prime} T$ mice. C, Averaged traces of EPSCs for WT M (black), WTL (gray), $L g^{\prime} T M$ (red), and L9' TL (pink). D, AtP12-P14, the mean EPSC amplitude was similar along the tonotopic map in WT (M: $n=9$ cells/7 animals, L: $n=10$ cells $/ 8$ animals, ANOVA, $F=0.027, p=0.87$ ) but not in $L 9^{\prime} T$ mice where the mean EPSC amplitude decreased in the lateral side (M: $n=11$ cells $/ 11$ animals, L: $n=12$ cells $/ 11$ animals, ANOVA, $F=5.07, p=0.0357$ ). G, Average traces at P20-P24 for WT M (black), WT L (gray), $L g^{\prime} T \mathrm{TM}$ (red), and L $9^{\prime} T \mathrm{~L}$ (pink). $\boldsymbol{H}$, The mean EPSC amplitude was similar for both WT (M: $n=$ 5 cells $/ 5$ animals, L: $n=5$ cells $/ 4$ animals, ANOVA, $F=0.0242, p=0.881)$ and $L g^{\prime} T(\mathrm{M}: n=6$ cells $/ 6$ animals; L: $n=9$ cells $/ 5$ animals, $F=0.05246, p=0.82)$ mice. In all cases, evoked synaptic currents were only recorded from principal neurons displaying EPSCS independent of stimulus intensity. The lack of statistical significance is most likely due to the larger data dispersion in the mutant mice $\left(\mathrm{CV}_{\mathrm{WT}}: 0.241 ; \mathrm{CV}_{L 9^{\prime}} ; 0.681\right)$. Error bars indicate mean $\pm \mathrm{SEM} .{ }^{*} p<0.05$.

A

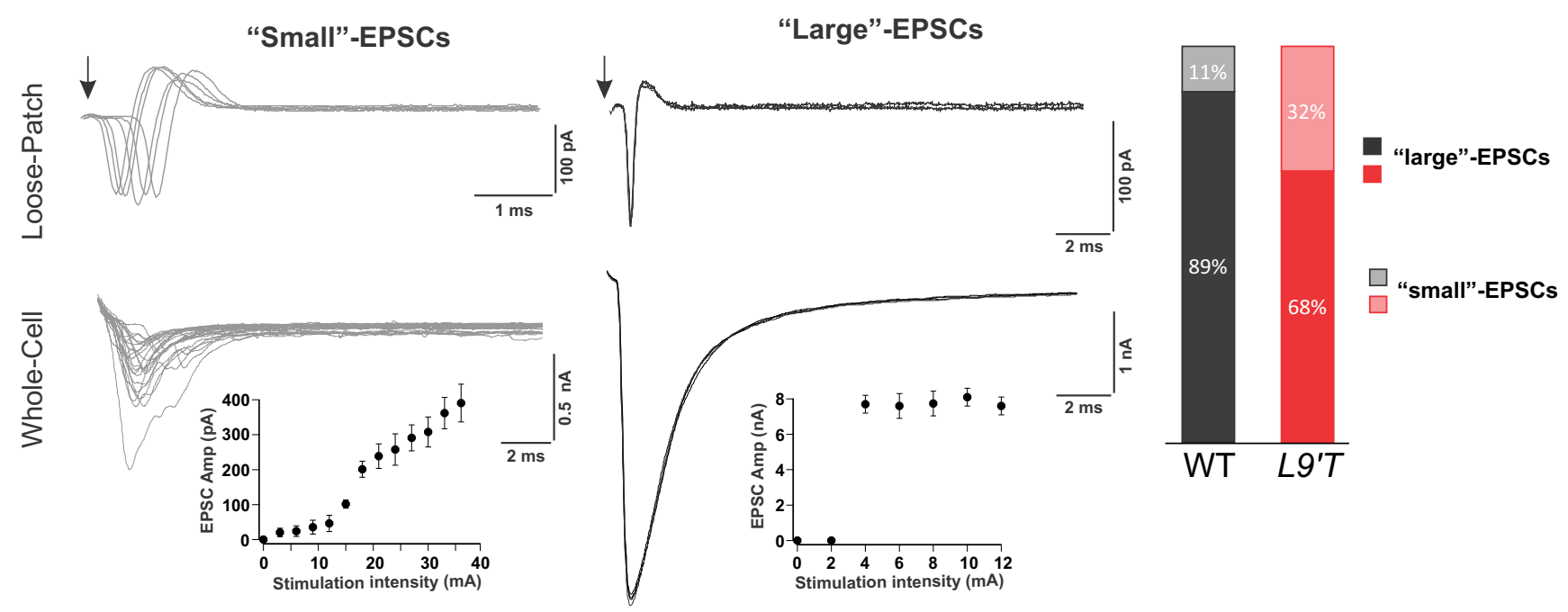

Figure 5. Small EPSCS were observed more frequently in $\angle 9^{\prime} T$ mice. A, Representative traces of two types of EPSCs evoked in MNTB principal neurons by stimulation of the trapezoid body. A large EPSC coming from a calyceal terminal (left) and small EPCSs from multiple terminals (right). Arrows indicate the position of the stimulation artifact. Cell-attached recordings (loose-patch configuration, top traces) show AP currents on MNTB cells. EPSCs were recorded in the whole-cell configuration (bottom traces). Calyceal EPSCs did not increase, whereas small EPSCs amplitude increased with higher stimulus intensity. Inset, Input- output curve shows a graded increase in EPSC amplitude with increasing stimulation intensity for "small" EPSCs but an all-or-none behavior for "large" EPSCS (mean \pm SEM). B, Percentage of cells with small or large inputs. A larger proportion of small-amplitude connections was observed in $\angle 9^{\prime} T$ mice. In WT mice, small EPSCs were $10 \%$ ( 4 of 35 cells, 11 animals), whereas this proportion was threefold larger in $L 9^{\prime} T$ mice $\left(31 \% ; 12\right.$ of 38 cells $/ 12$ animals; $\left.\chi^{2}=4.32, \mathrm{df}=1, p=0.019\right)$. 
A
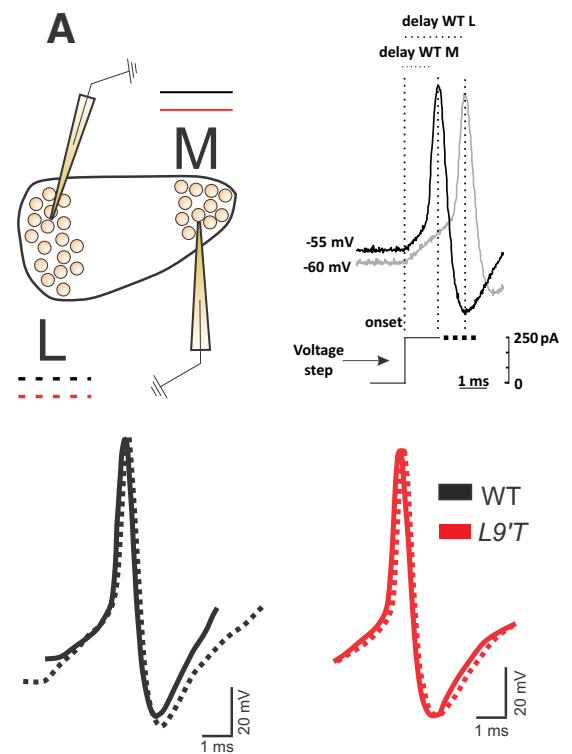

D
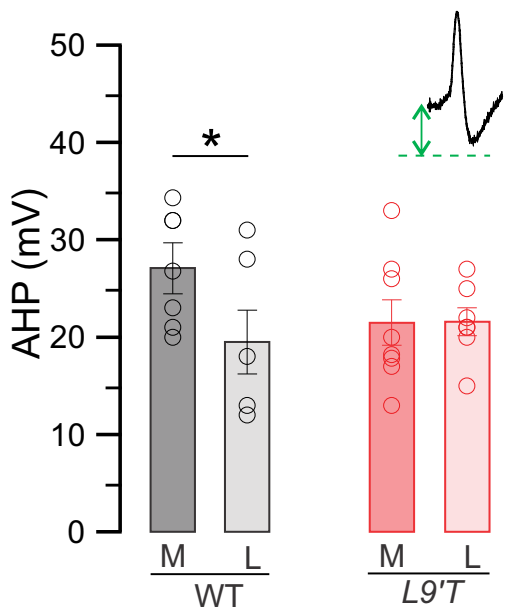

B

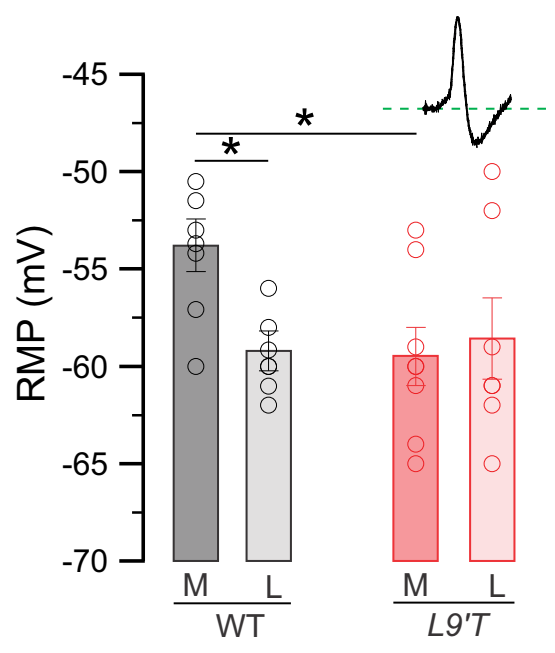

E

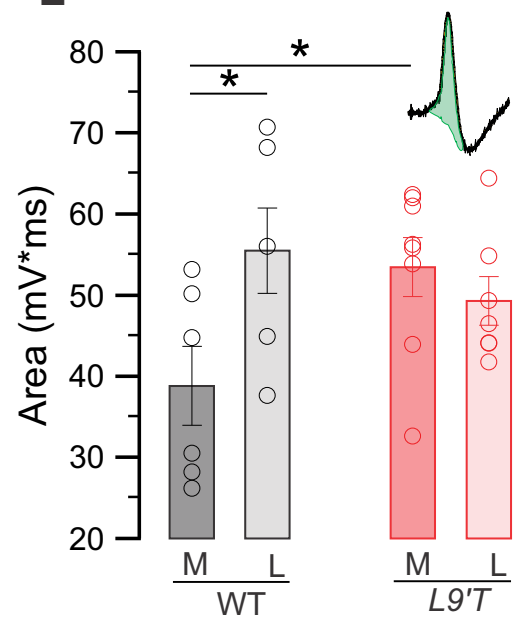

C
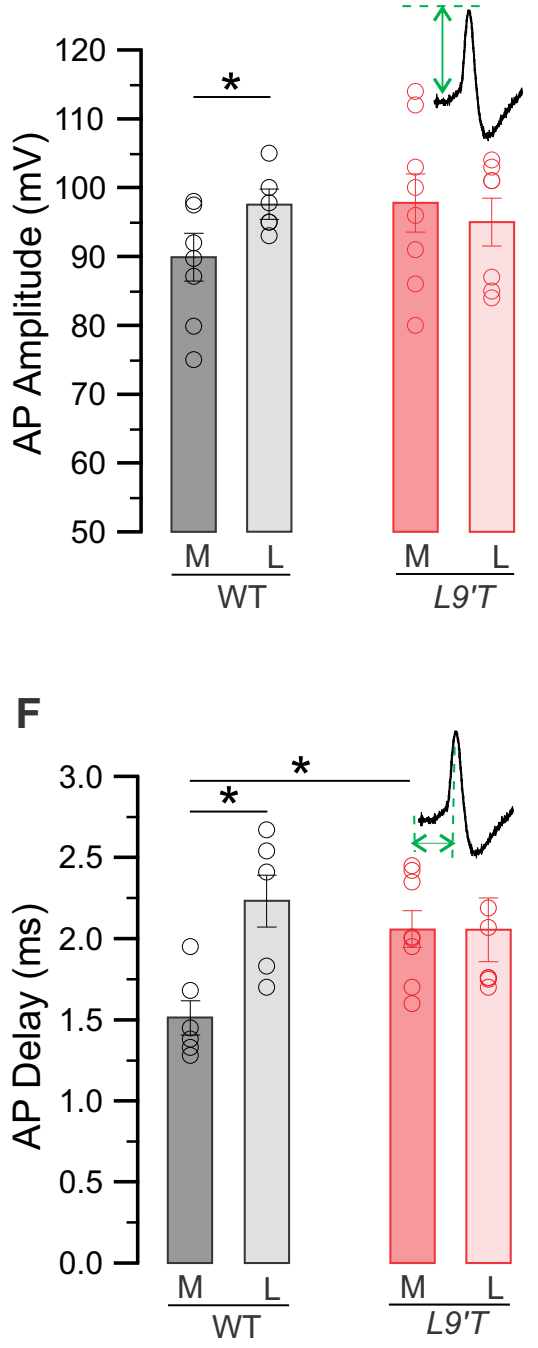

Figure 6. AP shape differed along the tonotopic axis in WT but not in $\angle 9^{\prime} T$ mice. $\boldsymbol{A}$, Top, Superimposed AP waveform of WT (black) and $\angle 9^{\prime} T$ (red) MNTB cells. Filled lines indicate the medial side. Dashed lines indicate the lateral side. Bottom, APs were aligned to their absolute amplitude showing that they reach similar peak voltages. $\boldsymbol{B}$, The RMP was more depolarized for medial than lateral cells in WT mice (M: $n=7$ cells $/ 5$ animals; L: $n=6$ cells $/ 5$ animals, ANOVA, $F=9.33, p=0.0013$ ). However, no ML differences were detected in $L 9^{\prime} T$ (M: $n=8$ cells $/ 7$ animals; L: $n=7$ cells $/ 7$ animals, ANOVA, $F=0.136, p=0.72$ ). AP features were quantified: AP amplitude $(\boldsymbol{C})$, after-hyperpolarization (AHP; $\boldsymbol{D})$, area $(\boldsymbol{E})$, and AP delay $(\boldsymbol{F})$. In all cases, ML differences in WT AP waveform were abolished in $\angle 9^{\prime} T$ mice. Error bars indicate mean \pm SEM. For additional information, see Table $2 .{ }^{*} p<0.05$.

Table 3. AP features

\begin{tabular}{|c|c|c|c|c|}
\hline & \multicolumn{2}{|l|}{ WT } & \multicolumn{2}{|l|}{$\angle 9^{\prime} T$} \\
\hline & M & $\mathrm{L}$ & M & $\mathrm{L}$ \\
\hline Amplitude (mV) & $89.88 \pm 1.41(n=7)$ & $97.61 \pm 0.98(n=6)^{a}$ & $97.75 \pm 1.49(n=8)$ & $95.01 \pm 1.31(n=7)$ \\
\hline $\mathrm{AHP}(\mathrm{mV})$ & $27.05 \pm 1.07(n=7)$ & $19.50 \pm 1.54(n=8)^{b}$ & $21.5 \pm 0.82(n=8)$ & $21.57 \pm 0.54(n=7)$ \\
\hline Area $\left(\mathrm{mV}^{*} \mathrm{~ms}\right)$ & $38.83 \pm 1.99(n=6)$ & $55.49 \pm 2.14(n=6)^{c}$ & $53.48 \pm 1.29(n=8)$ & $49.29 \pm 1.14(n=7)$ \\
\hline Delay (ms) & $1.51 \pm 0.04(n=6)$ & $2.23 \pm 0.07(n=6)^{d}$ & $2.06 \pm 0.04(n=8)$ & $2.05 \pm 0.07(n=7)$ \\
\hline
\end{tabular}

${ }^{a} F=5.518, p=0.038 ;{ }^{b} F=4.678, p=0.045 ;{ }^{C} F=5.418, p=0.042 ;{ }^{d} F=14.185, p=0.0037$.

(Babola et al., 2018). Johnson et al. (2011) have suggested that ACh released from efferent terminals is essential for setting a bursting firing pattern in apical IHCs. Moreover, Sendin et al. (2014) have shown that the pharmacological block of $\alpha 9 \alpha 10$ nAChRs elicits an increase in IHC spontaneous discharge rate. Additionally, normal levels of spontaneous activity in the MNTB, but altered temporal spiking patterns have been reported in $\alpha 9$ KO mice (Clause et al., 2014). Since MNTB spontaneous activity is originated in the cochlea (Tritsch et al., 2010), the latter obser- vations most likely arise from the lack of MOC innervation in these mutants and indicate a role of MOC efferent innervation in shaping prehearing auditory spontaneous activity. Using a mouse model with enhanced MOC efferent inhibitory strength, the present results support the notion that the transient $\alpha 9 \alpha 10$ mediated transmission to IHCs is crucial for modulating spikingdependent development of the auditory system. Since during development a modest stimulation rate of efferent fibers is sufficient to produce near-maximal inhibition of IHC firing (Moglie 
A

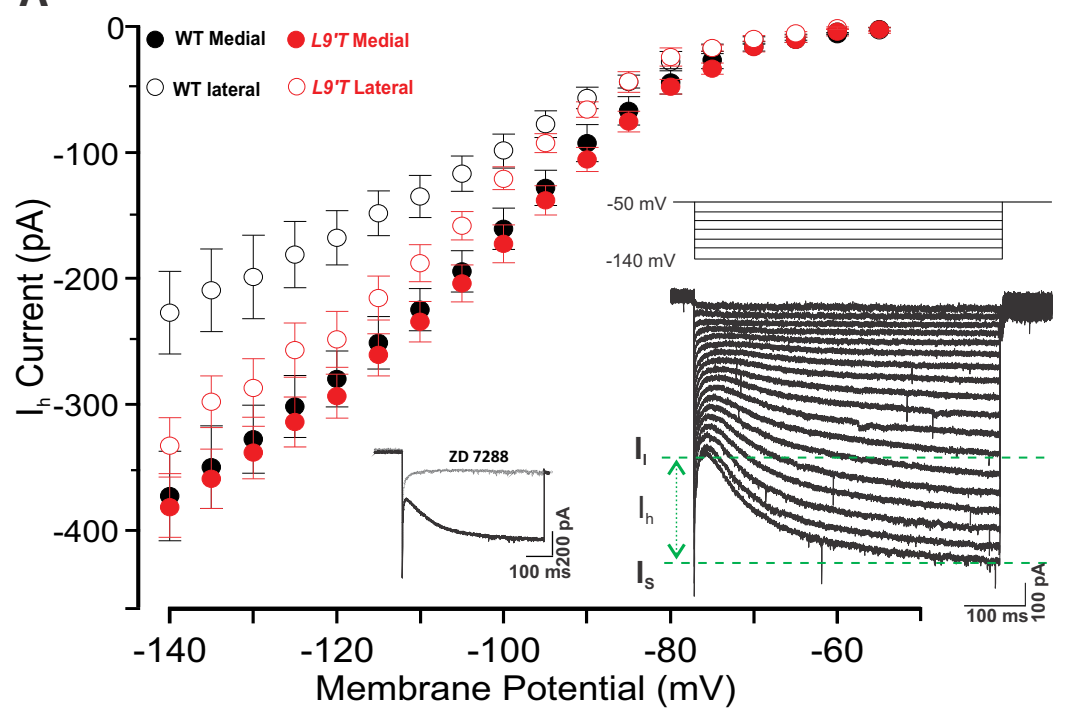

B

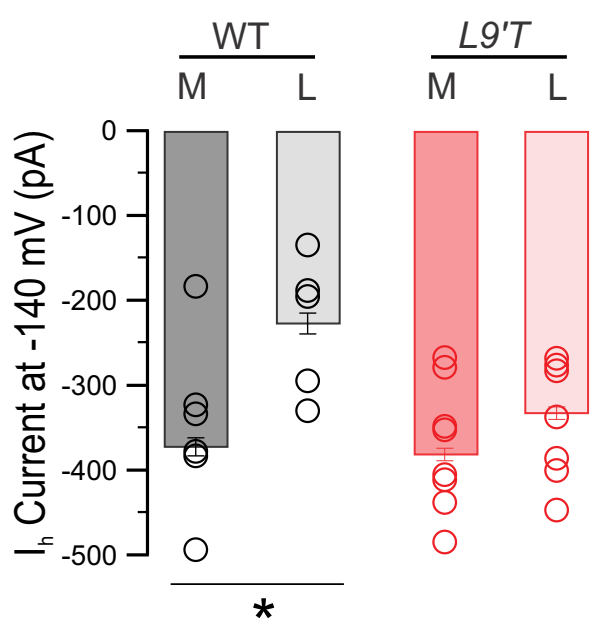

D

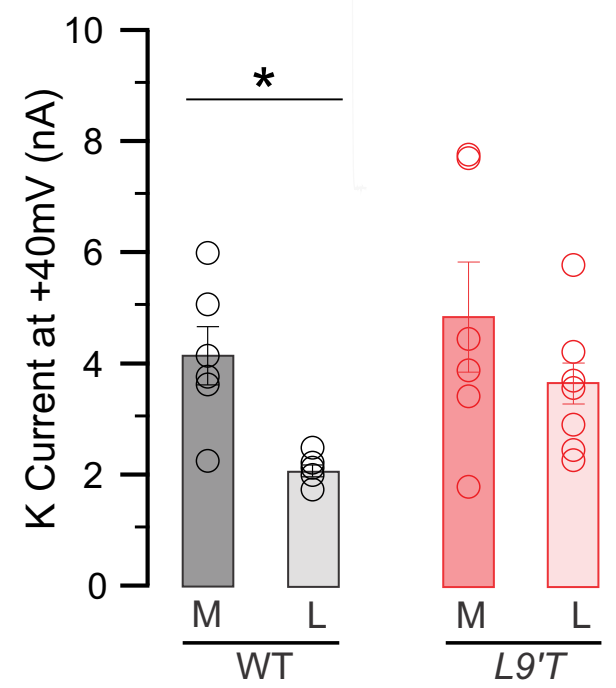

Figure 7. ML gradient of potassium currents was absent in $L 9^{\prime} T$ mice. $A, I-V$ relationship for $\mathrm{I}_{\mathrm{h}}$ currents exhibited a $M L$ gradient in WT, but this topographic difference disappeared in $L 9^{\prime} T$ mice. Error bars indicate mean \pm SEM. Inset, Representative traces of $\mathrm{I}_{\mathrm{h}}$ currents (WT M) elicited by hyperpolarizing voltage steps from -50 to $-140 \mathrm{mV}$ every $10 \mathrm{~s}$ for $0.5 \mathrm{~s}$ (right). Current responses consisted of an instantaneous inward current $\left(I_{1}\right)$ and a slowly developing inward current $\left(I_{S}\right) I_{h}$ amplitudes were determined as $I_{S}-I_{\text {. }}$. Representative $I_{h}$ trace at $-140 \mathrm{mV}$ after bath perfusion with the specific HCN channel blocker ZD 7288 ( $50 \mu \mathrm{m}$, left). B, Quantification of maximal $\mathrm{I}_{\mathrm{h}}$ current amplitude at $-140 \mathrm{mV}$ for WT (M: $n=11$ cells $/ 8$ animals; L: $n=7$ cells $/ 6$ animals, ANOVA, $F=7.89$, $p=0.013$ ) and $L 9^{\prime} T$ mice (M: $n=10$ cells $/ 7$ animals; $\mathrm{L}: n=9$ cells $/ 7$ animals, ANOVA, $F=2.22, p=0.156$ ). $C$, $I-V$ relationship displayed a larger potassium current in $M$ compared with $\mathrm{L}$ cells in WT mice, whereas this tonotopic distribution was absent in $L 9^{\prime} T$ mice. Error bars indicate mean \pm SEM. Inset, Representative traces at different depolarizing voltage steps (from -90 to $40 \mathrm{mV}$; $5 \mathrm{mV}$ increment during $1 \mathrm{~s})$ in the presence of $\mathrm{TTX}(3 \mu \mathrm{M}), \mathrm{CdCl}_{2}(50 \mu \mathrm{m})$, and ZD7288 $(50 \mu \mathrm{M})$. Potassium currents were measured in the steady-state region (within the last $50 \mathrm{~ms}$, green dashed lines). D, Maximal $\mathrm{K}^{+}$current amplitude at $40 \mathrm{mV}$ exhibits a ML gradient for WT (M: $n=6$ cells $/ 5$ animals; L: $n=6$ cells $/ 6$ animals, Mann-Whitney test, $Z=2.72, p=0.0065$ ) but not in $L 9^{\prime} T$ mice (M: $n=6$ cells $/ 6$ animals; L: $n=7$ cells $/ 6$ animals, Mann-Whitney test, $Z=1.01, p=0.32$ ). ${ }^{*} p<0.05$.

et al., 2018), and this inhibition is exacerbated in $L 9^{\prime} T$ mutant mice (Wedemeyer et al., 2018), the resultant phenotype most likely results from the silencing of IHC spiking activity. This is supported by the reduction of MNTB multiunit spiking activity observed in the mutants.

\section{Synaptic transmission}

In the absence of calcium channels responsible for the release of glutamate by the IHCs, development of synaptic transmission at the calyx of Held is impaired (Erazo-Fischer et al., 2007). Al- though these mice lack auditory nerve activity, experiments have not clearly distinguished between spontaneous and soundevoked afferent spiking. The reduction observed in wave III amplitude in the present work can derive from alterations in synaptic transmission at the calyx of Held in $L 9^{\prime} T$ mice because this peak of the ABR is dependent upon synchronous synaptic activity in the MNTB (Melcher et al., 1996; Kim et al., 2013). Thus, the increased number of asynchronic "small” EPSCs in mutant mice compared with the calyceal-monosynaptic synchronic stimulus intensity-independent EPSCs in WT can ac- 
count for this phenotypic observation. These asynchronic "small" EPSCs probably result from a lack of synaptic refinement in $L 9^{\prime} T$ mice, a dynamic process that takes place $\sim \mathrm{P} 2-\mathrm{P} 4$, when calyceal collaterals are pruned, gradually disappear, and eventually principal cells end up being contacted by a single calyx of Held (Hoffpauir et al., 2006, 2010; Rodríguez-Contreras et al., 2008; Holcomb et al., 2013). It is interesting to note that, although wave III amplitude changes in the mutants were weakest at $8 \mathrm{kHz}$, synaptic alterations were mainly observed in the lateral low-frequency region of the MNTB, an area that matures significantly later than the medial high-frequency region (Ford et al., 2009). This paradoxical result might derive from the fact that wave III reflects auditory processing at the SOC and that this complex comprises several nuclei, including the MNTB (Melcher et al., 1996). Therefore, significant amount of changes and/or compensation mechanisms might take place in other nuclei of the SOC in $L 9^{\prime} T$ mice.

The mechanisms leading to the persistence of immature calyces (eliciting asynchronic "small" EPSCs) in mutant mice is unknown but most likely reside on the lack of cues needed to strengthen competing synaptic inputs as described for the neuromuscular junction (Wu et al., 2010), the climbing fiber innervation of Purkinje cells (Watanabe and Kano, 2011), and the retinal ganglion cell innervation of the dorsal lateral geniculate nucleus (Hong and Chen, 2011). In this regard, the $L 9^{\prime} T$ mutant phenotype resembles that of the bone morphogenetic protein conditional $\mathrm{KO}$, with impaired nerve terminal growth, loss of mono-innervation, and less mature transmitter release properties (Xiao et al., 2013). It has been reported that developmental pruning of calyceal collaterals is independent of sound-evoked activity (Rodríguez-Contreras et al., 2008). The present results suggest that pruning is dependent upon the transient MOC efferent innervation that tightly controls spontaneous spiking activity.

The increased frequency of mEPSCs in mutant mice might derive from the higher number of cells contacted by multiple calyces. Thus, individual active zones from different axons could independently contribute to spontaneous release. Alternatively, changes in the expression of proteins involved in vesicle docking and priming, as well as $\mathrm{Ca}^{2+}$ sensors and other SNARE-binding proteins (Schneggenburger and Rosenmund, 2015), might lead to the same observation. Since evoked synaptic currents were only recorded from principal neurons contacted by a single calyx, the reduction in the amplitude of EPSCs indicates that, even in "mono-innervated" synapses, synaptic transmission is altered in $L 9^{\prime} T$ mutants. Moreover, the present results show that the intrinsic passive and active properties of MNTB cells, which are established during the early developmental period (Hoffpauir et al., 2006), were also altered in $L 9^{\prime} T$ mutant mice, suggesting upstream alterations in synaptic transmission from the MNTB to lateral SOC, an inhibitory pathway in the mammalian sound localization system (Kandler, 2004).

\section{Tonotopy}

Characteristic frequencies of neuronal responses to acoustic stimulation are tonotopically arranged. This is the result of a precise topography of connections that is preserved along the auditory pathway (Friauf and Lohmann, 1999; Rubel and Fritzsch, 2002). This tonotopy is maintained and/or reflected in the topographic arrangement of neuronal functional properties (Li et al., 2001; Barnes-Davies et al., 2004; von Hehn et al., 2004; Brew and Forsythe, 2005; Pienkowski and Harrison, 2005; Leao et al., 2006).

How is tonotopy shaped by spontaneous, sound-independent versus sound-evoked auditory nerve activity (Rubel and Fritzsch,
2002; Sanes and Bao, 2009)? Congenitally $d n / d n$ deaf mice exhibit alterations in the structural and functional topographic arrangement of several auditory nuclei, indicating disrupted tonotopy (Leao et al., 2006). Although initially considered as a model of disrupted spontaneous spiking activity (Durham et al., 1989), recent findings challenge this hypothesis. Thus, in $d n / d n$ mice, which bear a deletion in the transmembrane channel-like protein 1 (Kurima et al., 2002), prehearing IHCs develop normally and fire spontaneous calcium APs (Marcotti et al., 2006).

Experiments performed in $\alpha 9 \mathrm{KO}$ mice have shown normal levels of spontaneous activity in the MNTB but altered temporal spiking patterns (Clause et al., 2014). Moreover, although the overall tonotopy is maintained, the strengthening and silencing of inhibitory MNTB-LSO connections before hearing onset are impaired. This results in a reduced sharpening of functional topography, as the consequence of a reduction in axonal pruning. In the present work, we demonstrate that the enhancement of MOC activity, which leads to an overall reduction in spontaneous MNTB spiking activity, disrupts the topographic specificity of several MNTB characteristics. These include RMP, AP waveform, and both $\mathrm{I}_{\mathrm{h}}$ and potassium currents. Since these conductances allow accurate auditory transmission at high rates across MNTB neurons (Hooper et al., 2002; Barnes-Davies et al., 2004; Hassfurth et al., 2009; Mathews et al., 2010; Karcz et al., 2011; Khurana et al., 2012; Baumann et al., 2013), one could speculate that $L 9^{\prime} T$ mice display frequency discrimination impairments, similar to those reported for $\alpha 9 \mathrm{KO}$ mice (Clause et al., 2017). Based on the present results and those of Clause et al. (2014), we propose that the transient MOC efferent innervation to IHCs is a first checkpoint of auditory spontaneous activity. It is interesting to note that the dysfunction of this first checkpoint of IHC activity provided by MOC efferents (as exhibited in $\alpha 9 \mathrm{KO}$ and $L 9^{\prime} T$ knock-in mice) is not compensated by homeostatic mechanisms, such as described for Vglut3 KO mice, which lack IHC glutamatergic synaptic transmission (Babola et al., 2018). This might indicate that spontaneous activity in the auditory system is always dictated by the IHCs when these are functionally connected to spiral ganglion neurons. Since central auditory disfunction is observed both in $\alpha 9 \mathrm{KO}$ (Clause et al., 2014) and knock-in mice (present results), the transient MOC efferent transmission to the IHCs most likely provides the patterning and modulation of spiking activity, rather than acting as an on/off switch to spontaneous activity.

\section{References}

Babola TA, Li S, Gribizis A, Lee BJ, Issa JB, Wang HC, Crair MC, Bergles DE (2018) Homeostatic control of spontaneous activity in the developing auditory system. Neuron 99:511-524.e15.

Bal R, Oertel D (2000) Hyperpolarization-activated, mixed-cation current (I(h)) in octopus cells of the mammalian cochlear nucleus. J Neurophysiol 84:806-817.

Banks MI, Pearce RA, Smith PH (1993) Hyperpolarization-activated cation current (Ih) in neurons of the medial nucleus of the trapezoid body: voltage-clamp analysis and enhancement by norepinephrine and cAMP suggest a modulatory mechanism in the auditory brain stem. J Neurophysiol 70:1420-1432.

Barnes-Davies M, Forsythe ID (1995) Pre- and postsynaptic glutamate receptors at a giant excitatory synapse in rat auditory brainstem slices. J Physiol 488:387-406.

Barnes-Davies M, Barker MC, Osmani F, Forsythe ID (2004) Kv1 currents mediate a gradient of principal neuron excitability across the tonotopic axis in the rat lateral superior olive. Eur J Neurosci 19:325-333.

Baumann VJ, Lehnert S, Leibold C, Koch U (2013) Tonotopic organization of the hyperpolarization-activated current (Ih) in the mammalian medial superior olive. Front Neural Circuits 7:117.

Boero LE, Castagna VC, Di Guilmi MN, Goutman JD, Elgoyhen AB, Gómez- 
Casati ME (2018) Enhancement of the medial olivocochlear system prevents hidden hearing loss. J Neurosci 38:7440-7451.

Borst JG, Helmchen F, Sakmann B (1995) Pre- and postsynaptic whole-cell recordings in the medial nucleus of the trapezoid body of the rat. J Physiol 489:825-840.

Brew HM, Forsythe ID (2005) Systematic variation of potassium current amplitudes across the tonotopic axis of the rat medial nucleus of the trapezoid body. Hear Res 206:116-132.

Clause A, Kim G, Sonntag M, Weisz CJ, Vetter DE, Rubsamen R, Kandler K (2014) The precise temporal pattern of prehearing spontaneous activity is necessary for tonotopic map refinement. Neuron 82:822-835.

Clause A, Lauer AM, Kandler K (2017) Mice lacking the Alpha9 subunit of the nicotinic acetylcholine receptor exhibit deficits in frequency difference limens and sound localization. Front Cell Neurosci 11:167.

Durham D, Rubel EW, Steel KP (1989) Cochlear ablation in deafness mutant mice: 2-deoxyglucose analysis suggests no spontaneous activity of cochlear origin. Hear Res 43:39-46.

Elgoyhen AB, Johnson DS, Boulter J, Vetter DE, Heinemann S (1994) Alpha 9: an acetylcholine receptor with novel pharmacological properties expressed in rat cochlear hair cells. Cell 79:705-715.

Elgoyhen AB, Vetter DE, Katz E, Rothlin CV, Heinemann SF, Boulter J (2001) alpha10: a determinant of nicotinic cholinergic receptor function in mammalian vestibular and cochlear mechanosensory hair cells. Proc Natl Acad Sci U S A 98:3501-3506.

Erazo-Fischer E, Striessnig J, Taschenberger H (2007) The role of physiological afferent nerve activity during in vivo maturation of the calyx of Held synapse. J Neurosci 27:1725-1737.

Ford MC, Grothe B, Klug A (2009) Fenestration of the calyx of Held occurs sequentially along the tonotopic axis, is influenced by afferent activity, and facilitates glutamate clearance. J Comp Neurol 514:92-106.

Friauf E, Lohmann C (1999) Development of auditory brainstem circuitry: activity-dependent and activity-independent processes. Cell Tissue Res 297:187-195.

Glowatzki E, Fuchs PA (2000) Cholinergic synaptic inhibition of inner hair cells in the neonatal mammalian cochlea. Science 288:2366-2368.

Gómez-Casati ME, Fuchs PA, Elgoyhen AB, Katz E (2005) Biophysical and pharmacological characterization of nicotinic cholinergic receptors in rat cochlear inner hair cells. J Physiol 566:103-118.

Goodman CS, Shatz CJ (1993) Developmental mechanisms that generate precise patterns of neuronal connectivity. Cell 72 [Suppl]:77-98.

Goutman JD, Fuchs PA, Glowatzki E (2005) Facilitating efferent inhibition of inner hair cells in the cochlea of the neonatal rat. J Physiol 566:49-59.

Hanson MG, Landmesser LT (2004) Normal patterns of spontaneous activity are required for correct motor axon guidance and the expression of specific guidance molecules. Neuron 43:687-701.

Hassfurth B, Magnusson AK, Grothe B, Koch U (2009) Sensory deprivation regulates the development of the hyperpolarization-activated current in auditory brainstem neurons. Eur J Neurosci 30:1227-1238.

Hoffpauir BK, Grimes JL, Mathers PH, Spirou GA (2006) Synaptogenesis of the calyx of Held: rapid onset of function and one-to-one morphological innervation. J Neurosci 26:5511-5523.

Hoffpauir BK, Kolson DR, Mathers PH, Spirou GA (2010) Maturation of synaptic partners: functional phenotype and synaptic organization tuned in synchrony. J Physiol 588:4365-4385.

Holcomb PS, Hoffpauir BK, Hoyson MC, Jackson DR, Deerinck TJ, Marrs GS, Dehoff M, Wu J, Ellisman MH, Spirou GA (2013) Synaptic inputs compete during rapid formation of the calyx of Held: a new model system for neural development. J Neurosci 33:12954-12969.

Hong YK, Chen C (2011) Wiring and rewiring of the retinogeniculate synapse. Curr Opin Neurobiol 21:228-237.

Hooper SL, Buchman E, Hobbs KH (2002) A computational role for slow conductances: single-neuron models that measure duration. Nat Neurosci 5:552-556.

Johnson SL, Eckrich T, Kuhn S, Zampini V, Franz C, Ranatunga KM, Roberts TP, Masetto S, Knipper M, Kros CJ, Marcotti W (2011) Positiondependent patterning of spontaneous action potentials in immature cochlear inner hair cells. Nat Neurosci 14:711-717.

Johnson SL, Kennedy HJ, Holley MC, Fettiplace R, Marcotti W (2012) The resting transducer current drives spontaneous activity in prehearing mammalian cochlear inner hair cells. J Neurosci 32:10479-10483.

Johnson SL, Wedemeyer C, Vetter DE, Adachi R, Holley MC, Elgoyhen AB,
Marcotti W (2013) Cholinergic efferent synaptic transmission regulates the maturation of auditory hair cell ribbon synapses. Open Biol 3:130163.

Jones TA, Leake PA, Snyder RL, Stakhovskaya O, Bonham B (2007) Spontaneous discharge patterns in cochlear spiral ganglion cells before the onset of hearing in cats. J Neurophysiol 98:1898-1908.

Kandler K (2004) Activity-dependent organization of inhibitory circuits: lessons from the auditory system. Curr Opin Neurobiol 14:96-104.

Kandler K, Friauf E (1993) Pre- and postnatal development of efferent connections of the cochlear nucleus in the rat. J Comp Neurol 328:161-184.

Karcz A, Hennig MH, Robbins CA, Tempel BL, Rübsamen R, KoppScheinpflug C (2011) Low-voltage activated Kv1.1 subunits are crucial for the processing of sound source location in the lateral superior olive in mice. J Physiol 589:1143-1157.

Karplus M, Lee C, Cashore WJ, Oh W (1988) The effects of brain bilirubin deposition on auditory brain stem evoked responses in rats. Early Hum Dev 16:185-194.

Katz E, Elgoyhen AB, Gómez-Casati ME, Knipper M, Vetter DE, Fuchs PA, Glowatzki E (2004) Developmental regulation of nicotinic synapses on cochlear inner hair cells. J Neurosci 24:7814-7820.

Khurana S, Liu Z, Lewis AS, Rosa K, Chetkovich D, Golding NL (2012) An essential role for modulation of hyperpolarization-activated current in the development of binaural temporal precision. J Neurosci 32:28142823.

Kim SE, Turkington K, Kushmerick C, Kim JH (2013) Central dysmyelination reduces the temporal fidelity of synaptic transmission and the reliability of postsynaptic firing during high-frequency stimulation. J Neurophysiol 110:1621-1630.

Kirkby LA, Sack GS, Firl A, Feller MB (2013) A role for correlated spontaneous activity in the assembly of neural circuits. Neuron 80:1129-1144.

Koch U, Braun M, Kapfer C, Grothe B (2004) Distribution of HCN1 and HCN2 in rat auditory brainstem nuclei. Eur J Neurosci 20:79-91.

Kotak VC, Sanes DH (1995) Synaptically evoked prolonged depolarizations in the developing auditory system. J Neurophysiol 74:1611-1620.

Kros CJ, Ruppersberg JP, Rüsch A (1998) Expression of a potassium current in inner hair cells during development of hearing in mice. Nature 394: 281-284.

Kurima K, Peters LM, Yang Y, Riazuddin S, Ahmed ZM, Naz S, Arnaud D, Drury S, Mo J, Makishima T, Ghosh M, Menon PS, Deshmukh D, Oddoux C, Ostrer H, Khan S, Riazuddin S, Deininger PL, Hampton LL, Sullivan SL, et al. (2002) Dominant and recessive deafness caused by mutations of a novel gene, TMC1, required for cochlear hair-cell function. Nat Genet 30:277-284.

Leake PA, Hradek GT, Chair L, Snyder RL (2006) Neonatal deafness results in degraded topographic specificity of auditory nerve projections to the cochlear nucleus in cats. J Comp Neurol 497:13-31.

Leao RN, Sun H, Svahn K, Berntson A, Youssoufian M, Paolini AG, Fyffe RE, Walmsley B (2006) Topographic organization in the auditory brainstem of juvenile mice is disrupted in congenital deafness. J Physiol 571:563578.

Li W, Kaczmarek LK, Perney TM (2001) Localization of two high-threshold potassium channel subunits in the rat central auditory system. J Comp Neurol 437:196-218.

Lipovsek M, Im GJ, Franchini LF, Pisciottano F, Katz E, Fuchs PA, Elgoyhen AB (2012) Phylogenetic differences in calcium permeability of the auditory hair cell cholinergic nicotinic receptor. Proc Natl Acad Sci U S A 109:4308-4313.

Lippe WR (1994) Rhythmic spontaneous activity in the developing avian auditory system. J Neurosci 14:1486-1495.

Marcotti W, Johnson SL, Rusch A, Kros CJ (2003) Sodium and calcium currents shape action potentials in immature mouse inner hair cells. J Physiol 552:743-761.

Marcotti W, Erven A, Johnson SL, Steel KP, Kros CJ (2006) Tmc1 is necessary for normal functional maturation and survival of inner and outer hair cells in the mouse cochlea. J Physiol 574:677-698.

Mathews PJ, Jercog PE, Rinzel J, Scott LL, Golding NL (2010) Control of submillisecond synaptic timing in binaural coincidence detectors by K(v)1 channels. Nat Neurosci 13:601-609.

Melcher JR, Knudson IM, Fullerton BC, Guinan JJ Jr, Norris BE, Kiang NY (1996) Generators of the brainstem auditory evoked potential in cat: I. An experimental approach to their identification. Hear Res 93:1-27.

Moglie MJ, Fuchs PA, Elgoyhen AB, Goutman JD (2018) Compartmental- 
ization of antagonistic $\mathrm{Ca}(2+)$ signals in developing cochlear hair cells. Proc Natl Acad Sci U S A 115:E2095-E2104.

Pienkowski M, Harrison RV (2005) Tone frequency maps and receptive fields in the developing chinchilla auditory cortex. J Neurophysiol 93:454-466.

Rodríguez-Contreras A, van Hoeve JS, Habets RL, Locher H, Borst JG (2008) Dynamic development of the calyx of Held synapse. Proc Natl Acad Sci U S A 105:5603-5608.

Rubel EW, Fritzsch B (2002) Auditory system development: primary auditory neurons and their targets. Annu Rev Neurosci 25:51-101.

Rusu SI, Borst JG (2011) Developmental changes in intrinsic excitability of principal neurons in the rat medial nucleus of the trapezoid body. Dev Neurobiol 71:284-295.

Sanes DH, Bao S (2009) Tuning up the developing auditory CNS. Curr Opin Neurobiol 19:188-199.

Schneggenburger R, Rosenmund C (2015) Molecular mechanisms governing $\mathrm{Ca}(2+)$ regulation of evoked and spontaneous release. Nat Neurosci 18:935-941.

Sendin G, Bourien J, Rassendren F, Puel JL, Nouvian R (2014) Spatiotemporal pattern of action potential firing in developing inner hair cells of the mouse cochlea. Proc Natl Acad Sci U S A 111:1999-2004.

Shapiro SM (1988) Acute brainstem auditory evoked potential abnormalities in jaundiced Gunn rats given sulfonamide. Pediatr Res 23:306-310.

Shaw NA (1988) The auditory evoked potential in the rat: a review. Prog Neurobiol 31:19-45.

Simmons DD, Mansdorf NB, Kim JH (1996) Olivocochlear innervation of inner and outer hair cells during postnatal maturation: evidence for a waiting period. J Comp Neurol 370:551-562.

Sonntag M, Englitz B, Kopp-Scheinpflug C, Rübsamen R (2009) Early postnatal development of spontaneous and acoustically evoked discharge activity of principal cells of the medial nucleus of the trapezoid body: an in vivo study in mice. J Neurosci 29:9510-9520.

Taranda J, Maison SF, Ballestero JA, Katz E, Savino J, Vetter DE, Boulter J, Liberman MC, Fuchs PA, Elgoyhen AB (2009) A point mutation in the hair cell nicotinic cholinergic receptor prolongs cochlear inhibition and enhances noise protection. PLoS Biol 7:e18.

Taschenberger H, Leão RM, Rowland KC, Spirou GA, von Gersdorff H (2002) Optimizing synaptic architecture and efficiency for highfrequency transmission. Neuron 36:1127-1143.

Taschenberger H, Scheuss V, Neher E (2005) Release kinetics, quantal parameters and their modulation during short-term depression at a developing synapse in the rat CNS. J Physiol 568:513-537.

Tritsch NX, Bergles DE (2010) Developmental regulation of spontaneous activity in the mammalian cochlea. J Neurosci 30:1539-1550.

Tritsch NX, Yi E, Gale JE, Glowatzki E, Bergles DE (2007) The origin of spontaneous activity in the developing auditory system. Nature 450:50-55.

Tritsch NX, Rodríguez-Contreras A, Crins TT, Wang HC, Borst JG, Bergles DE (2010) Calcium action potentials in hair cells pattern auditory neuron activity before hearing onset. Nat Neurosci 13:1050-1052.

Vetter DE, Liberman MC, Mann J, Barhanin J, Boulter J, Brown MC, SaffioteKolman J, Heinemann SF, Elgoyhen AB (1999) Role of alpha9 nicotinic ACh receptor subunits in the development and function of cochlear efferent innervation. Neuron 23:93-103.

Vetter DE, Katz E, Maison SF, Taranda J, Turcan S, Ballestero J, Liberman MC, Elgoyhen AB, Boulter J (2007) The alpha10 nicotinic acetylcholine receptor subunit is required for normal synaptic function and integrity of the olivocochlear system. Proc Natl Acad Sci U S A 104:20594-20599.

von Hehn CA, Bhattacharjee A, Kaczmarek LK (2004) Loss of Kv3.1 tonotopicity and alterations in CAMP response element-binding protein signaling in central auditory neurons of hearing impaired mice. J Neurosci 24:1936-1940.

Wang HC, Lin CC, Cheung R, Zhang-Hooks Y, Agarwal A, Ellis-Davies G, Rock J, Bergles DE (2015) Spontaneous activity of cochlear hair cells triggered by fluid secretion mechanism in adjacent support cells. Cell 163:1348-1359.

Warr WB, Guinan JJ Jr (1979) Efferent innervation of the organ of Corti: two separate systems. Brain Res 173:152-155.

Watanabe M, Kano M (2011) Climbing fiber synapse elimination in cerebellar Purkinje cells. Eur J Neurosci 34:1697-1710.

Wedemeyer C, Vattino LG, Moglie MJ, Ballestero J, Maison SF, Di Guilmi MN, Taranda J, Liberman MC, Fuchs PA, Katz E, Elgoyhen AB (2018) A gain-of-function mutation in the alpha9 nicotinic acetylcholine receptor alters medial olivocochlear efferent short-term synaptic plasticity. J Neurosci 38:3939-3954.

Weisstaub N, Vetter DE, Elgoyhen AB, Katz E (2002) The alpha9alpha10 nicotinic acetylcholine receptor is permeable to and is modulated by divalent cations. Hear Res 167:122-135.

Wimmer VC, Horstmann H, Groh A, Kuner T (2006) Donut-like topology of synaptic vesicles with a central cluster of mitochondria wrapped into membrane protrusions: a novel structure-function module of the adult calyx of Held. J Neurosci 26:109-116.

Wu H, Xiong WC, Mei L (2010) To build a synapse: signaling pathways in neuromuscular junction assembly. Development 137:1017-1033.

Xiao L, Michalski N, Kronander E, Gjoni E, Genoud C, Knott G, Schneggenburger R (2013) BMP signaling specifies the development of a large and fast CNS synapse. Nat Neurosci 16:856-864.

Yi E, Roux I, Glowatzki E (2010) Dendritic HCN channels shape excitatory postsynaptic potentials at the inner hair cell afferent synapse in the mammalian cochlea. J Neurophysiol 103:2532-2543. 